\title{
16. ve 18. Asırlarda Osmanlı Fetva Literatüründe Mudârebe Ortaklı̆̆
}

\author{
Ahmet İnanir \\ Doç. Dr., Tokat Gaziosmanpaşa Üniversitesi İlahiyat Fakültesi, İslam Hukuku Anabilim Dalı \\ Assoc. Dr., Gaziosmanpaşa University, Faculty of Theology, Department of Islamic Law \\ Tokat, Turkey \\ ahmet.inanir52@gop.edu.tr \\ orcid.org/0000-0001-8300-2682
}

\section{6. and 18. Century Mudārabah Contract in Ottoman Fatwas Literature}

\section{Abstract}

Mudārabah is a type of partnership that was founded by putting labor on the one hand and capital on the other, dating back thousands of years before Islam. In Islam, this partnership has been accepted as legitimate and used by Muslim societies. This partnership has included in the classic fiqh books as a separate section from the şarikah subjects. Mudārabah partnership continues to exist in various ways today. Participation finance which is developing day by day collects capital based on this partnership. Some researchers even recommend it as an alternative method to participation banking based on contemporary usury especially the interest finance system. For this reason, whether the partnership in question is of a nature to perform the task expected from it will only be revealed by knowing the historical experience. Furthermore, determining the change that this partnership has undergone in the historical process will help to understand its current situation and the way it will take in the future. Because, depending on the human experience in the historical process, it is seen that some provisions and consequences of the partnership have changed. The partnership structures, which were simple in the first periods, have gained more and more technical features. For this reason, it is of great importance in terms of economic history to determine and how the Ottoman period partnerships were established in the 16 . and 18 . centuries, which business lines were widely used, and what legal problems and solutions were produced during this period. In this way, functional determinations can be made as to whether the contract will be able to fulfill the function expected today.

This research tries to put forward the various legal problems and solutions faced by the conflict partnership based on Ottoman fatwa literature in the 16. - 18. centuries. Because the current problems encountered with the application have been the subject of fatwas as well as fiqh books. Fort this purpose, fatwa journals belonging to Ibn Kemal (d. /9401534), Ebu's-su'ud Efendi (Abū l-Su'ūd) (d. 982/1574), Sun'ullah Efendi (d. 1021/1612), Feyzullah Efendi (d. 1115/1703) and Yenişehirli Abdullah Efendi (d. 1156/1743), who stand out in terms of recognition and accessibility in the aforementioned centuries have been collected and fatwas that can be determined on the subject have been evaluated. In the Ottoman period fatwa literature, the contractual contract takes place in separate titles separate from the company department, as in the tradition of fiqh. It is understood that fatwas related with mudārabah mostly reflect the problems and solutions that arise during the application. When the

İtihal Taraması/Plagiarism Detection: Bu makale intihal taramasından geçirildi/This paper was checked for plagiarism Geliş/Received: 09 Ocak/January 2020 |Kabul/Accepted: 25 Şubat/February 2020 |Yayın/Published: 20 Mart/March 2020 Atff/Cite as: Ahmet İnanır, “16. ve 18. Asırlarda Osmanlı Fetva Literatüründe Mudârebe Ortaklığı Teriminin İçerdiği Anlamlar = 16. and 18. Century Mudārabah Contract in Ottoman Fatwas Literature”, Eskiyeni 40 (Mart/March 2020), 37-72. https://doi.org/10.37697/eskiyeni.672541

Copyright () Anadolu Illahiyat Akademisi/Anatolian Theological Academy, 06050, Ankara, Turkey |www.anilakademi.com CC BY-NC 4.0 | This paper is licensed under a Creative Commons Attribution-NonCommercial License 
prominent fatwa journal of the research subject are examined, it is seen that the mudārabah partnership has been widely used in Ottoman society in terms of both number and issues. Due to the fact that this partnership can be said to be one of the most useful tools for the capitalist to operate his capital and to meet the financing needs for the entrepreneur. It seems that some people especially women, who do not have the opportunity to trade, prefer this partnership.

Expressions such as "Zeyd Captain", "Black Sea and the Mediterranean", which are frequently mentioned in mudārabah related to fatwas are observed that a partnership has been made mainly in the Istanbul-centered, Mediterranean and Black Sea basins for the agricultural and commercial works in the Ottoman Empire in the aforementioned centuries. Thus, entrepreneurs seem to meet their shortterm financing needs. It can be said that the fact that the mudärabah partner is active in the partnership and the passivity of the capital owner causes the parties to have more reflections in the fatwa than the other partnership types. Because, it is seen that if the mudārabah partner is not unjust due to the mudārabah partnership, he is not responsible for the loss in his capital, and if the profits are due to the transactions against the immigration of the capital owner, the probability of the mudārabah partner is to take more risks.

This situation causes the capital owner to try to impose various restrictions on the place, time and duration in order to protect the capital from loss, and even to go further, to put forward some conditions contrary to the spirit of the depository, as the depository is common to the loss in the capital or to be a guarantor to the capital. Nevertheless, it is understood that the depository did not comply with the relevant conditions too much and that in some cases the capital was lost, this was considered within the scope of injustice.

One of the main points of disagreement between the capital owner and the mudārabah partner whether the capital is given as debt, treatment or mudarabah. Especially, in case mudārabah partnership makes a loss, it is seen that capital owner is trying to save his main capital, while the mudārabah partner is trying to avoid the obligation of compensation. Even, in some fatwas, capital may claim that while he took profit from the mudārabah partner, he made a profit in the event that the loss occurred while the nature of the capital was not on the agenda. He claims that he/she took the ruin in response to his/her claim that the capital owner lent. In fatwas, if the partners can not put forward any evidence or if both parties present the evidence, the evidence of debt is accepted, if no preference can be made a selection between the evidences, it is seen that if capital get lost, debt is preferable, if profit is obtained, the evidence of mudārabah is preferred. Because, the mudārabah partner with the permission of capital owner, admits that he/she delivered the goods in capital owner, according to which he embraced capital. In this case, mudārabah partner may file suit a compensation case. However, if there is no evidence related capital owner lends, it is accepted that his/her oath related to mudārabah partner is a mudarabah.

It is seen that the capital owner is trying to make a capital such as wheat, hemp, cloth and sheep in fatwas. However, if he gave a power of attorney and told him to use it, it is seen that the contract of mudārabah could not draw up. In addition, except for the labor of the mudārabah partner, the claim that he added capital and was the permission of the capital owner etc. is accepted in some circumstances. It can be said that the issues of loss and detriment related to mudārabah are subject to more fatwa than other issues. Some of them appear to be due to negligence and malevolent attitude of the destructor, some to be due to negative market conditions, and others to physical adverse conditions such as the sinking of the ship. From these point, it is also possible to identify the areas where the damage was caused in these centuries. Among them, the sinking and side lying of the sea vehicles come to the fore. It can be said that in the centuries of research in the example of Mudarabah, there is no incompatibility between the fatwas and the tradition of fiqh, that is between theory and practice.

\section{Keywords}

Islamic Law, Ottoman Empire, Fatwas, Company, Mudārabah Contract 


\section{6. ve 18. Asırlarda Osmanlı Fetva Literatüründe Mudârebe Ortaklığ1}

\section{Öz}

Mudârebe, geçmişi İslam'dan binlerce yll öncesine dayanan bir taraftan emek, diğer taraftan sermaye konularak kurulan bir ortaklık türüdür. İslam'da da bu ortaklık meşru olarak kabul edilmiş ve Müslüman toplumlar tarafından kullanılmıştır. Bu ortaklık klasik fikıh kitaplarında şirket bahsinden ayrı bir bölüm olarak yer almıştır. Mudârebe ortaklığı çeşitli şekillerde günümüzde de varlığını devam ettirmektedir. Her geçen gün gelişmekte olan katılım finansı bu ortaklığa dayalı olarak sermaye toplamaktadır. Hatta bazı araştırmacılar onu faizli finans sistemi başta olmak üzere çağdaş murabahaya dayalı katılım bankacılı̆̆ına alternatif bir yöntem olarak da önermektedir. Bu yüzden söz konusu ortaklığın günümüzde kendisinden beklenen görevi yapacak bir mahiyette olup olmadığı ancak tarihi tecrübenin bilinmesiyle ortaya çıkacaktır. Ayrıca bu ortaklığın tarihi süreçte geçirdiği değişimin tespit edilmesi onun günümüzdeki durumunu ve gelecekte alacağ 1 şeklin anlaşılabilmesine yardımcı olacaktır. Zira tarihi süreçte beşerî tecrübeye bağlı olarakmudârebe ortaklığında bazı hüküm ve neticelerinin değişime uğradığı görülmektedir. İlk dönemlerde sade olan ortaklık yapıları gittikçe daha teknik bir özellik kazanmaktadır. Bu sebeple 16. ve 18. asırlarda Osmanlı dönemi mudârebe ortaklıklarının nasıl ve ne biçimde kurulduğu, hangi iş kollarında yaygın bir şekilde kullanıldığı ve bu esnada ne gibi hukuki sorunların çıktığı ve çözümlerin üretildiğinin tespit edilmesi iktisat tarihi açısından büyük önem arz etmektedir. Bu sayede mudârebenin günümüzde kendisinden beklenen işlevi yerine getirip getiremeyeceğinin imkânına dair işlevsel tespitler yapilabilecektir.

Bu araştırma 16-18. asır Osmanlı fetva literatürüne dayalı mudârebe ortaklığının söz konusu asırlarda karşılaştığı çeşitli hukuki sorunlar ve çözümlerini ortaya koymaya çalışmaktadır. Çünkü uygulamayla ilgili karşılaşılan güncel sorunlar fikıh kitapları yanında fetvalara konu olmuştur. Bu amaçla söz konusu asırlarda tanınırlık ve ulaşılabilirlik bakımından öne çıkan İbn Kemal (öl. 940/1534), Ebussuûd Efendi (öl. 982/1574), Sunullah Efendi (öl. 1021/1612), Feyzullah Efendi (öl. 1115/1703) ve Yenişehirli Abdullah Efendi'ye (öl. 1156/1743) ait fetva mecmûaları taranarak konuyla ilgili tespit edilebilen fetvalar değerlendirilmiştir.

Osmanlı dönemi fetva literatüründe mudârebe akdi, fikıh geleneğinde olduğu gibi şirket bölümünden ayrı müstakil başlıklarda yer almaktadır. Mudârebeyle ilgili fetvaların daha çok uygulama esnasında ortaya çıkan sorunlar ve çözümleri yansıttığı anlaşılmaktadır. Araştırma konusu asırlara ait öne çıkan fetva mecmuaları incelendiğinde gerek sayı gerekse ihtiva ettiği konular bakımından mudârebe ortaklığının Osmanlı toplumunda vavgın bir sekilde kullanıldığı görülmektedir. Zira bu ortaklık sermayedar açısından sermavesini işletmenin, girişimci açısından da finansman ihtiyacını karşılamanın en kullanışlı araçlarından biri olduğu söylenebilir. Özellikle kadınlar olmak üzere ticaret yapma imkânı olmayan bazı kimseler bu ortaklığı tercih ettikleri anlaşılmaktadır.

Mudârebevle ilgili fetvalarda sıkca gecen denizle ilgili "Zeyd-i reis", "Karadeniz ve Akdeniz" gibi ifadeler söz konusu asırlarda Osmanlı Devleti'nde daha çok İstanbul merkezli Akdeniz ve Karadeniz havzasında tarım ve ticarete vönelik ișler için mudârebe ortaklığı vapıldığı görülmektedir. Bu sayede girişimciler, kısa vadeli finansman ihtiyaçlarını karşıladıkları anlaşılmaktadır. Mudâribin ortaklıkta faal, rabbü'l-mâlin pasif kalması tarafların diğer ortaklık türlerine göre mudârebevle ilgili meselelerin daha fazla fetvalara yansımasına sebep olduğu söylenebilir. Çünkü mudârebe ortaklı̆̆ı gereği mudâribin teaddisi olmadığı takdirde re'sümâldeki zarardan sorumlu olmaması ve rabbü'l-mâlin takyidine muhalif yaptığı işlemlerden dolayı kâr etmesi halinde kârın kendisine kalmasıyla mudâribin daha fazla risk almasına imkân verdiği görülmektedir.

Bu durum rabbü'l-mâlin sermayesini zarardan korumak amacıvla mudâribe yer, zaman ve süreyle ilgili çeşitli sınırlamalar getirmeye çalı̧masına hatta daha da ileri giderek mudâribin sermayedeki zarara müşterek olması veya sermayeye kefil olması gibi fikıhta yer aldığı şekliyle mudârebe akdinin ruhuna avkırı bazı sartlar ileri sürmesine sebep olmaktadır. Buna rağmen mudâribin ilgili sartlara pek fazla riâvet etmeverek bazı hallerde sermayenin zâyî olmasına sebep olduğu bunun ise teaddi kapsamında değerlendirildiği anlaşılmaktadır. 
Rabbü'l-mâl ile mudâribin temel ihtilaf noktalarından birinin de re'sümâlin karz, muâmele veya mudârebe olarak verilip verilmediği meselesidir. Özellikle ortaklı̆ıın zarar etmesi halinde rabbü’lmâl, ana sermayesini kurtarmak, mudâribin ise tazmin yükümlülü̆üunden kaçınmak için uğraştığ görülmektedir. Hatta bazı fetvalarda rabbü'l-mâl, mudâribden kâr payı alırken, sermayenin mahiyetini gündem yapmazken zarar ortaya çıktığı hallerde karz verdiğini iddia edebilmektedir. Burada rabbü'l-mâlin karz verdiği iddiasına karşılık, mudârib mudârebeye aldığını ileri sürmektedir. Fetvalarda ortaklar herhangi bir delil ortaya koyamadığı veya her iki tarafın delil ortaya koyduğu hallerde karz delili kabul edilmekte, deliller arasında herhangi bir tercih yapılamadığ takdirde ise sermaye zâyî olmuşsa karz, kâr elde edilmişse mudârebe delilinin tercih edildiği görülmektedir. Çünkü mudârib, rabbü'l-mâlin izniyle sermayeyi kabzettiğine göre rabbü'l-mâl de malı teslim ettiğini itiraf etmektedir. Bu durumda mudâribe tazmin davası açabilir. Ancak rabbü'l-mâlin karz verdiğine dair delili olmadığı hallerde mudâribin mudârebe olduğuna dair yemini kabul edilir.

Fetvalarda rabbü'l-mâlin buğday, kendir, bez ve koyun gibi taşınır malları re'sümâl yapmaya çalıştığı görülmektedir. Ancak rabbü'l-mâl vekâlet verip mudârebeye kullanmasını söylenediği takdirde mudârebe akdi kurulmuş olmadığı görülmektedir. Ayrıca mudâribin emeği dışında kendisinin sermave ilave ettiğine dair iddiası rabbü'l-mâlin izin vermesi vb. bazı sartlarda kabul edilmektedir. Mudârebevle ilgili zarar ve zivan hususlarının diğer meselelere göre daha fazla fetvalara konu olduğu sövlenebilir. Bunların bir kısmı mudâribin ihmal vekötü nivetli tutumundan bir kısmı olumsuz pivasa sartlarından diğer bir kısmı da geminin batması gibi fizikî olumsuz sartlardan kavnaklandı̆̆ı görülmektedir. Bunlardan hareketle söz konusu asırlarda zararın kavnaklandığı alanları tespit etmek de mümkündür. Bunlar arasında deniz araçlarının batma ve yan yatmaları öne çıkmaktadır. Mudârebe akdi örneğinde araştırma yapılan asırlarda fetvalarla fikıh geleneği arasında yani teori ile pratik arasinda bir uyumsuzluğa rastlanmadığ söylenebilir.

\section{Anahtar Kelimeler}

İslam Hukuku, Osmanlı Devleti, Fetvalar, Şirket, Mudârebe

\section{Giriş}

İlk dönemlerden itibaren ellerinde sermayeleri olup çeşitli sebeplerle işletemeyen bazı kimselerin ticari kabiliyeti olduğuna güvendiği kişilerle mudârebe yoluyla sermayelerini işletmeleri, İslam öncesi farklı medeniyetler tarafindan da bilinen ve uygulana gelen bir yöntemdir. Milattan yaklaşık iki bin yıl önce yaşamış Kral Hammurabi'nin kanunnamelerinde. Talmud'da ve Roma hukukunda mudârebeyi çağrıştıran ortaklıklara rastlanmaktadır. Câhiliye devri Arapları arasında da mudârebe ortaklığının Mekke'nin Bizans, Pers ve Yemen arasında ticaret güzergâhındaki konumu dolavısıyla hem kervan hem de deniz ticaretinde finansman ihtiyacını karşılamanın en kullanışlı araçlarından biri olduğu bilinmektedir. Nitekim Hz. Muhammed (s.a.v.) peygamber olmadan önce Hz. Hatice ile mudârebe ortaklı̆̆ı yaptığı belirtilmektedir. ${ }^{2}$ Birçok sahabenin de bu ortaklığı yaptıkları bilinmektedir. ${ }^{3}$

1 Murtaza Köse, “Ticaret Hukuku Tarihi Açısından Mudârebe ve Commenda Ortaklıklarının Etkileşimi Hakkında Bir Deneme”, Atatürk Üniversitesi İlahiyat Fakültesi Dergisi 17 (2002), 159-160.

2 Merğînânî, Ali b. Ebî Bekir b. Abdulcelil, el-Hidâve serh-u Bidâveti'l-mubtedî, thk. Tallâl Yusuf (Bevrut: Dâru kütübi'l-ilmivve, 1990), 3/225; İbn Hazm, Ebû Muhammed Ali b. Ahmed b. Saîd el-Endelüsîel-Kurtubîez-Zahirî, el-Muhallâ bi'l-âsâr (Beyrût: Dârü'l-i̇lmive, 1988), 7/96; Abdülaziz İzzet Havyat, es-Serikât fi's-Seriati'l-íslamiyye ve'l-Kanunu'l-Vaz'i, 4. Baskı (Bevrut: Müessetür'r-risale, 1994), 1: 63; Cengiz Kallek, "Mudârebe”, Türkiye Diyanet Vakfi İslâm Ansiklopedisi (İstanbul: TDV Yayınları, 2005), 30/359-363.

3 İbn İshak, Muhammed b. İshak b. Yesar, Siretï İbn İshak, tah. Muhammed Hamidullah (Konya: Hayra Hizmet Vakfi Yayıncılık, 1981), 59; İbnü'l-Esir İzzuddin Ebi'l-Hasan Ali b. Ebi'l-Kerem Muhammed b. Mu- 
Mudârebe, Avrupa'da da 10. vüzyıldan itibaren "commenda” adıvla bir çeșit âdi komandit sirket biçiminde vavgınlașı bölge ülkelerinin ticaret hukukuna girerek standart bir görünüm kazanmıs, is ortaklıklarının daha çok girişimci ve sermayedarı bünyesinde toplamasına katkı sağlamıştır. ${ }^{4}$ Dolayısıyla bu ortaklık sadece Müslümanların geliştirdikleri ve yararlandıkları bir ortaklık değil, insanlığın ortak tecrübesinin ürünüdür. ${ }^{5}$ İktisat tarihinde bu ortaklığı işleticinin zarardan sorumlu olmaması ve sermaye sahibinin yatırdığı sermaye kadar sorumlu sayılması bakımından sınırlı sorumluluk kavramının tezahür etiği ortaklık türü olarak değerlendirilmektedir. ${ }^{6}$

Beşerî muamelelerin sürekli değişmesi sonucu daha önce literatürde olmayan yeni ortaklıklar icat edildiği gibi var olan ortaklıkların da şartları, hükümleri ve neticeleri değişebilmektedir. Bu bağlamda mudârebe ortaklığının ticârî örfe göre değiștiği görülmektedir. Zira ilk dönemlerde oldukça sade ortaklık vapıları gittikçe daha teknik bir özelliğe kavușmakta hatta günümüzde "Mülkivetle Sona Eren Mudârebe", "Müsterek Mudârebe" ve "Mudârebe Sukuk" gibi içinde mudârebe ismi geçen çeşitli bileşik (mürekkep) ortaklıklar geliştirilmeye çalışılmaktadır. Örneğin mudârabe sukuku, klasik mudârabeye göre taraflar, yapı ve niteliğiyle ilgili bazı değişimler geçirmektedir. Zira klasik mudârebe iki taraflı basit bir sözleşme iken mudârabe sukuk ise üç taraflı, mudârabe ve satım akdinin bir akitte birlestiği mürekkeb bir akde dönüșmektedir. Mudârebe ortaklığı katılım bankalarının da kuramsal temelini olusturmaktadır. ${ }^{8}$ Cünkü katılım hesaplarına toplanan fonlar mudârebe usulüyle toplanmakta ve teorik olarak ticaret basta olmak üzere sanavi, hizmet ve tarım sektörlerinde faalivet göstermek üzere mudârebe ortaklıkları kurabilmektedir. Nitekim katılım bankalarının kurucu öncülerinden Ahmed en-Neccâr asıl olarak ortaklık vöntemini önermektedir. ${ }^{9}$ Ancak uygulamada ticaretin doğası gereği taşıdığı risklerden dolayı

hammed b. Abdilkerim b. Abdilvahid Şeybani, el-Kâmil fi't-tarih, (Beyrut: 1965), 2/39; Hattâb, Abdurrahman Muhammed b. Muhammed, Mevâhibu'l-celil li-şerhi Muhtasar-ı Halil, thk. Zekeriya Umeyrât (Beyrut: Dâr-u âlimi'l-kütüb, 2003), 7/440.

4 Halil Arslanl, Kollektif ve Komandit Şirketler (İstanbul: İstanbul Üniv. Yay. 1958), 8; Osman Şekerci, İslâm Şirketler Hukuku (İstanbul, Marifet Yayıncılık, 1981), 37-38; Fethi Gedikli, Osmanlı Şirket Kültürü: XVI.-XVII. Yüzyllarda Mudârebe Uygulaması (İstanbul: İz Yayıncılık, 1998), 56-60.

5 Merğînânî, Hidâye, 3/225.

6 Tansu Çiller - Murat Çizakça, Türk Finans Kesiminde Sorunlar ve Reform Önerileri, (İstanbul: İstanbul sanayi Odası Yayıncllı, 1989), 7; Kallek, "Mudârebe", 30/362; Köse, "Ticaret Hukuku Tarih Açısından Mudârebe ve Commenda Ortaklıklarının Etkileşimi Hakkında Bir Deneme”, 171.

7 Komisvon, Faizsiz Bankacılık Standartları, Çev. İshak Emin Aktepe/Mehmet Odabaşı (İstanbul: TKBB Yayıncılık, 2012), 370; Servet Bayındır, Fıkhî ve İktisâdî Açıdan İslâmî Finans (Para ve Sermaye Piyasaları) (İstanbul: Süleymaniye Vakfi Yayıncılık, 2015), 142-143; Abdullah Durmuş, "Modern Bir Finansal Araç Olarak Sukuk ve Fıkhi Açıdan Tahlili”, İslam Hukuku Arastırmaları Deraisi 16 (2010), 147; Ahmet Hamdemirci ve Sakir Görmüs. “Kapitalizm'in Sarmalından Bir Çıkış Yolu Olarak Adil Ekonomik Düzen'in Kredileşme İlkeleri”, Route Education and Social Science Journal 27 (2018); 1306-1307; Abdulelah al-Zafenî, Mudârebe Şirketlerinin Akitleri ve Çağdaş Uygulanırlı̆ğ (İstanbul: Sabahattin Zaim Üniversitesi, Sosyal Bilimler Enstitüsü, Yüksek Lisans Tezi, 2017), 3.

8 Gedikli, Osmanl Şirket Kültürü, 59-60; Kallek, "Mudârebe", 30/360.

9 Ahmed en-Neccâr, el-Asâle ve'l-muâsıra fî menheci tenmiyeti’ş-şâmile; Bünûk bilâ fevâid kadiyyetü bünûki'l-iddihâri'l-mahalliyye (Cidde: 1985; 79-270); Refik Yunus el-Misrî, Buhûs fi'l-mesârifi'l-İslâmiyye (Dımaşk: Dâru'l-fikr, 2001), 332-381. 
pek tercih edilmemektedir. ${ }^{10}$ Buna rağmen bazı araștırmacılar mudârebeyi faizli finans sistemi başta olmak üzere çağdaş murabahava davalı katılım bankacılığına alternatif bir yöntem olarak da önermektedir. ${ }^{11}$ Bu sebeple günümüzde mudârebeden daha fazla yararlanma imkânı araştııılmaktadır.

Diğer taraftan 1970'lerden itibaren Amerika Birleșik Devletleri'nde teknoloiik veniliklere ait projelerin finansmanını sağlamakta vararlanılan "risk sermavesi" (venture capital), her ne kadar mudârebevle mahivet farklılı̆̆ı bulunsa da zarar riskini sermayedarın yüklenmesi bakımından mudârebeve benzetilmektedir. ${ }^{12}$

Klasik fikıh literatüründe ilk dönemlerden itibaren çesitli ortaklık türlerine ver verilmektedir. Ancak fikıh terminoloiisinde sirket kavramı teknik olarak ortaklık gaveli akitlerin hepsini kapsamamakta daha çok ortakların sermave, pav ve haklarının avnı çesit olduğu ortaklıkları ifade etmektedir. Bu sebeple böyle olmavan ortaklıklar "kitâbü's-sirke" bölümünde değil de müstakil bașlıklar altında ele alınmaktadır. Emek-sermaye ortaklığına dayanan mudârebe de müstakil basslıklarla "kırad" ve "mudârabe" gibi isimlerle adlandırılmaktadır. ${ }^{13}$ Osmanlı Devleti hukuk sisteminde, Hanefi mezhebi esas alındığından Osmanlı dönemi fikıh ve fetva literatüründe genellikle mudârebe ismi kullanılmaktadır. ${ }^{14}$

Mudârebe konusunda şimdiye kadar gerek yurt içinde gerek ise yurt dışında çeşitli araştırmaların yapıldığı görülmektedir. ${ }^{15}$ Türkiye'de Fethi Gedikli'nin 1996 yılında "16. ve 17. Astr Osmanl Şer'iyye Sicillerinde Mudârebe Ortaklı̆ı: Galata Örneği" adlı doktora tezinin bu alanda yapılmış en kapsamlı çalışmalardan biri olduğu söylenebilir. ${ }^{16}$ Yazar burada sınırlı sayıda fetvâdan yararlanmakta ve bunları uygulamadan kaynaklanan sorunlardan ziyade teorik bir kaynak olarak değerlendirmektedir. ${ }^{17}$ Ayrıca Hasan Ellek'in "İslam Hukuku’nda Emek-Sermaye Ortaklı̆ı (Mudârebe) ve Diğer Ortakliklarla İlişkisi” ve Abdulelah al-Zafenînin "Mudârebe Şirketlerinin Akitleri ve Çağdaş Uygulanırlığı" adlı yüksek lisans tez çalışmaları vardır. Murtaza Köse'nin "Ticaret Hukuku Tarihi Açısından Mudârebe ve Commenda Ortaklklartnın Etkileșimi Hakkında Bir Deneme"18, Fethi Gedikli'nin “İstanbul'da Para Vakıfları

10 Yunus Emre Yıldız, Kamu Kurumlarının Finansmaninda Mudârebe Imkânlarının Uygulanmast (İstanbul: Sabahattin Zaim Üniversitesi, Sosyal Bilimler Enstitüsü, Yüksek Lisans Tezi, 2019), 32; İmran Çelik, "Meşru Bir Yatırım Aracı Olarak Mudârebe ve Günümüzde Kullanımı", Injosos Al-Farabi International Iournal On Social Sciences/ Al-Farabi Uluslararast Sosval Bilimler Deraisi 1/3 (2017). 392-394 (381-395): Obivathulla Ismath Bacha. "Conventional Versus Mudārabah Financing: An Agency Cost Perspective", Journal of Islamic Economics 4/1-2 (Selangor 1995), 33-49.

11 Çelik, "Meşru Bir Yatırım Aracı Olarak Mudârebe ve Günümüzde Kullanımı", 382; Yıldız, Kamu Kurumlarının Finansmaninda Mudârebe İmkânlarının Uygulanması, 21.

12 Gedikli, Osmanl Şirket Kültürü, 59-60; Köse, "Ticaret Hukuku Tarih Acısından Mudârebe ve Commenda Ortaklıklarının Etkileşimi Hakkında Bir Deneme”, 160-161; Kallek, "Mudârebe”, 30/360.

13 Hattâb, Mevâhibu'l-celil, 7/440.

14 Merğînânî, Hidâye, 3/225; Ebussuûd, Muhammed İmâduddin, Mecmûatü'l-Fetâvâ, Derleyen Velî b. Yusuf (İstanbul: İstanbul Müftülüğü Kütüphanesi, 178), vr. 150b-153a.

15 İlgili çağdas literatür icin bk. Zafenînin “Mudârebe Sirketlerinin Akitleri ve Cağdas Uvgulanırlığı”, 156-163.

16 Bu tez "Osmanlı Sirket Kültürü: XVI XVII. Yüzyıllarda Mudârebe Uygulaması” adıyla İz Yayıncılık tarafindan 1998 yılında basılmıştır.

17 Tahsin Özcan, “Osmanlı Şirket Kültürü: XVI. -XVII. Yüzyıllarda Mudârebe Uygulaması”, İslâm Araştırmaları Dergisi 3 (1999), 273-275.

18 Köse, “Ticaret Hukuku Tarihi Açısından Mudârebe ve Commenda Ortaklıklarının Etkileşimi Hakkında Bir Deneme", 151-177. 
ve Mudârebe"19, M. Salih Kumaş ve Elman Abdullayev'in "Bir Finansman Modeli Olarak Mudârebe'nin FaizsizBankacilkta Etkin SekildeKullanilması Sürecinde Sivil Toplum Öraütlerinin Aktif Rol Üstlenmesi”"20 Doruk Gönen, "İslam Hukukunda Mudârebe (Emek+Sermaye) Şirketinde Tarafların Hak ve Borçlar"”"1, Muhammed Vecih Huneyni'nin "Tasmîmu hryârâti mâliyye İslâmiyye li'lmudârebe ve idâreti'l-mehâtır"22, Sahnun Mahmudve Hannan el-Umravi'nin "Sukûkü'l-mudârebeti'l-hadrâ ve devruhâ fi tahkîki mukavvemâti't-tenmiyeti'l-müstedâme” çalışmaları tespit edilmiştir. ${ }^{23}$ Şirketler hukuku alanındaki diğer çalışmalar da dikkate alındığında mudârebe ortaklığının birçok yönden çalışıldığı söylenebilir. Ancak Osmanlı fetva literatürüne dayalı araştırmalar son derece sınırlıdır. Bu çalışma 16. ve 17. asırlarda mudârebe ortaklığında karşılaşılan çeşitli hukuki sorunlar ve çözümleri değerlendirmeye çalışacaktır. Bu amaçla yüzü aşkın fetva tespit edilip kendi içinde konularına göre tasnif edilerek hem Osmanlı dönemi tecrübesi hem de teorik fikhîhükümler ile arasındaki tutarlılığa dair bazı tespitler yapabilme imkânı araştırılacaktır. Nihayetinde mudârebe ortaklığıyla ilgili daha gerçekçi değerlendirme yapılmasına zemin oluşturacaktır. Bu çalışmada ayrıca söz konusu fetva metinleri olduğu gibi verilerek o dönemdeki sorunların açık bir şekilde anlaşılması ve çeşitli disiplinlerden araştırmacıların istifade etmesi amaçlanmaktadır. Dolayısıyla bu çalışmanın alanında mudârebeyle ilgili fetvalara dayalı farklı bir boşluğu doldurması amaçlanmaktadır.

Mudârebe ortaklığı klasik fikıh kitaplarında ve çağdaş çeşitli çalışmalarda ayrıntılı bir şekilde incelenmiş ${ }^{24}$, Mecelle'de ise kanunlaşmıştır. ${ }^{25} \mathrm{Bu}$ yüzden burada sadece Hanefi mezhebi bağlamında teorik açıdan kısaca mudârebeye yer verilecek daha çok araştırma konusu asırlara ait fetvalar üzerinden konu anlaşılmaya çalışılacaktır.

\section{1. İslam Hukukunda Mudârebe}

Mudârebe akdi, ortaklardan birinin sadece sermayesini, diğerinin ise emek, ticari bilgi ve tecrübesini ortaya koyduğu ve tarafların kârı aralarında anlaştıkları oran

19 Fethi Gedikli, “istanbul'da Para Vakıfları ve Mudârebe”, Osmanlı Hukuku: Makaleler (İstanbul: Gündoğan Yayınları, 2012), 31-47.

20 M. Salih Kumaş ve Elman Abdullayev, "Bir Finansman Modeli Olarak Mudârebe'nin Faizsiz Bankacılıkta Etkin Şekilde Kullanılması Sürecinde Sivil Toplum Örgütlerinin Aktif Rol Üstlenmesi”, International Journal of Islamic Economics and Finance Studies = Uluslararasi İslam Ekonomisi ve Finansi Araştırmaları Dergisi 2/1 (2016), 67-87.

21 Doruk Gönen, "islam Hukukunda Mudârebe (Emek+Sermaye) Şirketinde Tarafların Hak ve Borçları", Istanbul Üniversitesi Hukuk Fakültesi Mecmuasl (IÜHFM) 63/1-2 (2005), 193-212.

22 Muhammed Vecih Huneyni, "Tasmîmu Hiyârâti Mâliyye İslâmiyye li'l-Mudârebe ve İdâreti'lMehâtır", International Congress on Islamic Economics and Finance (ICISEF) (21-23 October 2015), (Sakarya: Turkey Proceedings, 2016), 2/233-262.

23 Sahnun Mahmud-Hannan el-Umravi, "Sukûkü'l-Mudârebeti'l-Hadrâ ve Devruhâ fî Tahkîki Mukavvemâti't-Tenmiyeti'l-Müstedâme", International Congress on Islamic Economics and Finance (ICISEF) 21-23 October 2015 (Sakarya: Turkey Proceedings, 2016), 3/210-220; Özcan, "Osmanlı Şirket Kültürü: XVI. -XVII. Yüzvillarda Mudârebe Uvgulaması". 3/273-275.

24 Ebû Bekr Şemsü'l-eimme Muhammed b. Ebî Sehl Ahmed es-Serahsî, Mebsut, (XXX), (Bevrut: Dâru'l-marife, 1993), 22/18-187; Merğînânî, Hidâye, 3/225-239; Alâüddîn Ebû Bekr b. Mes'ûd b. Ahmed el- Kâsânî, Kitabu Bedâiu's-Sanâi fi Tertibi's-Serai, (I-VII), (Beyrut: Dâru'l-kütübi'l-ilmiyye, 1986), 6/79-114; Ebû Zekeriyyâ Yahyâb. Şeref b. Mürî en-Nevevî, el-Mecmu şerhu'l-Mühezzeb, (I-XX), (Beyrut: Dâru'l-fikr, tsz), 14/357-394; Şekerci, İslâm Şirketler Hukuku, 247-356.

25 Mecelle, Mad. 1404-1430. 
çerçevesinde paylaştıkları bir ortaklıktır. ${ }^{26} \mathrm{Bu}$ ortaklıkta sermaye sahibine rabbü'lmâl/finansör (pasif ortak), iş gücünü ve ticari kabiliyetlerini ortaya koyarak çalışan kimseye de mudârib veya âmil (aktif ortak veya girişimci) denir. Mecelle'de "Bir taraftan sermâye ve diğer taraftan sa'y ü amel olmak üzre bir nevi' şirkettir. Sermâye sahibine, "rabbü'l-mal" ve âmile, "mudârib" denilir" şeklinde tarif edilmektedir. ${ }^{27}$ Bu ortaklık iki kişi arasında yapılabileceği gibi işin mahiyetine göre birden fazla finansör ve girişimciyle de vapılabilir.

Mudârebe ortaklığı, gerekli ehlivete sahip tarafların karsılıklı irade bevanlarıvla (icap-kabul) kurulur. Hanefîlere göre karşılıklı irade bevanı mudârebenin rüknü, taraflarla akdin konusunu oluşturan sermaye ve amelle kârın oran olarak belirlenmesi ise sıhhat şartlarıdır. ${ }^{28}$ Mudârebede sermaye; para cinsinden olmalıdır, para dışında taşınır bir mal (uruz) olması caiz değildir. ${ }^{29}$ Zira sermayedarın kâra hak kazanması sermayesi ile mudâribin kâra hak kazanması ise emeğiyledir. Zarar ve ziyan her durumda finansöre aittir. ${ }^{30} \mathrm{Kâr}$ taksimatı ise sözleşmeye bağlıdır, ama genel ilke kâr tarafların anlaştıkları şarta, zarar da mal miktarlarına bağlıdır. Kârın belirsizliğini gerektiren her şart bu ortaklığı fasid kılar. ${ }^{31}$ Fakihlerden Ebu Yusuf ve Muhammed'e göre, mudârebe ortaklığı fasid olması halinde bu ortaklık fasid icareye dönüşür. Bu durumda şirket kâr etsin yahut etmesin, mudârib emeğinin karşılığı olarak ecr-i misil alır. Kâr, sırf sermayedâr için şart koşulduğu takdirde bu muamelenin adı "bidaa"32 , kâr sırf mudârib için şart koşulduğu takdirde ise bu akit "karza" dönüşür. ${ }^{33}$ Bazen de inan şirketi olarak kurulan ortaklık taraflardan biri tarafından işletildiği takdirde mudarebeye dönüşmektedir. ${ }^{34}$

Mudârebe ortaklı̆̆ı, bir emanet ilişkisini ve vekâleti kapsar yani ortaklık sermayesi olan re'sülmal mudâribin elinde vedia hükmündedir, dolayısıyla emanet sorumluluğuna bağlıdır. ${ }^{35}$ Çünkü aralarındaki ilişki, vekil-müvekkil arasındaki ilişki gibidir. Taraflardan birinin lehine, örneğin kârın bir kişiye ait olması şeklinde ileri sürülen şartlar, mudârebe akdini fasid kılmaktadır. Bu durumda mal, mudâribin elinde emanet hükmündedir. ${ }^{36}$ Teaddisi bulunmadığı takdirde mudârib, sermayede meydana gelecek zararlardan sorumlu değildir. ${ }^{37}$

26 Merğînânî, Hidâye, 3/226; Serahsi, Mebsut, 22/18-22; İbnü'l-Hümam Kemalüddin Muhammed b. Abdilvahid b. Abdülhamid. b. Mes’ud, Şerhu Fethi'l-Kadir, (I-X), (Beyrut: Dâru'l-Fikr, 1977), 10/445.

27 Mecelle, Md. 1404.

28 Merğı̂nânî, Hidâye, 3/226; Şekerci, İslâm Şirketler Hukuku, 282-287.

29 Serahsi, Mebsut, 22/33; Kâsânî, Bedâiu's-Sanâi, 6/83; Mecelle, Md. 1409.

30 Zarar ve ziyân, her halde rabbü'l-male âid olur. Ve mudârib ile beynlerinde müşterek olması şart edilirse, ol şarta i'tibar olunmaz. (Mecelle, Md. 1428).

31 Serahsi, Mebsut, 22/22; Kâsânî, Bedâiu's-Sanâi, 6/80; Şurunbilali Ebu'l-i̇hlas Hasan b. Ammar b. Ali el-Vefai, Gunyetü Zevi'lAhkam fi Buğyeti Düreri'l-Hükkam, (I-II), (İstanbul: 1976), 2/311, (Dürer'in haşiyesi olup birlikte basim).

32 Yenişehirli Abdullah Efendi, Behcetü'l- Fetava Maa'n-Nükul, (İstanbul: Dârü’t-Tibâati'l-Âmire, 1266), 491.

33 Merğı̂nânî, Hidâye, 3/225; Avnî, Ebu Muhammed Bedrüddin Mahmud b. Ahmed b. Musa el-Ayıntabi, elBinaye fi Şerhi'l-Hidaye (Beyrut: Dârü'l-Fikr, 1980), 5/657.

34 Yenişehirli Abdullah Efendi, Behcetü'l-Fetava, 483.

35 Serahsi, Mebsut, 2/19; Kâsânî, Bedâiu's-Sanâi, 6/87.

36 Merğînânî, Hidâye, 3/226; İbn Kemal, Îzâhu'l-Islâh, vr. 169a, vr. 256a.

37 İbn Kemal, Îzâhu'l-Islâh, vr. 169a; Mecelle, Mad. 1404. 
Mudâribin şirket işlerini yürütürken ortaklık sözleşmesindeki şartlara riayet etmesi gerekir. Bunlara riayet etmemesi halinde mudâribin gâsıp hükmünde olacağı ve oluşacak zararın tazmini gibi bazı yaptırımlar bulunmaktadır. ${ }^{38}$ Yine bu ortaklıkta aktif ortak olan mudâribin ortaklık sermayesinin fazlasıyla herhangi bir mal alımında bulunamayacağı ifade edilmektedir. ${ }^{39}$

Mudârebe ortaklığı sermaye sahibi ile mudâribe karşılıklı birtakım yükümlülükler getirir. Fakat sermaye sahibi akdin gerektirdiği sorumluluklar dıșında sermavesini zarardan korumava vönelik akdin vapısıvla celismevecek kâr pavlasımı dısında zaman, mekân, ticaret çesidi, satıcı ve müsteri tavini gibi pek çok konuda tedbir sadedinde veya bir şekilde yararlı olacağını düşündüğü ilave şartlar ileri sürebilir. Bu şekilde yapılan mudârebeye mukayyed mudârebe, hiçbir şart ileri sürülmeden yapilan mudârebeye mutlak mudârebe denir. ${ }^{40}$ Mudârebede aslolan mutlak ifadelerle kurulmasıdır. Bu yüzden sermaye sahibi ile mudârib, işletme yeri ve peşin ya da veresiye ile işletme şekli konusunda ihtilafa düşseler mudâribin sözü geçerlidir. ${ }^{41}$ Şimdi burada daha fazla detaya girmeden 16-18. yüzyıl fetva literatürü bağlamında konu incelenmeye çalışılacaktır.

\section{16 - 18. Yüzyll Fetva Literatüründe Mudârebe}

Osmanlı Devleti, insan yapısı, kültür ve coğrafya bakımından kendisinden önceki Türk-İslâm devletlerinin bir devamıdır. Hukuk bakımından da bazı istisnalar dışında bu gelenek aynen devam etmiş, diğer Türk devletlerinde olduğu gibi Hanefi mezhebine bağlı kalınmıştır. Bu mezhep devletin kuruluş yıllarına kadar her yönüyle gelişmiş ve olgunlaşmıştır. ${ }^{42}$ Hanefi mezhebi ise her ne kadar Irak'ta ortaya çıksa da asıl gelişimini Maveraünnehir fikı h havzasında gerçekleştirmiştir. Bu fakihler klasik hukuk çalışmaları yanında, bir de günlük hayatın sorunlarına çözüm üreten nevâzil ve fetâvâ türünde eserler telif etmişlerdir. Osmanlı şeyhülislamları da resmi görev icabı muteber fikıh kitapları yanında bu eserlerden de istifade ederek ibadetler dâhil hayatın bütün alanlarını kapsayan güncel sorunlara fetvalar vermişlerdir. Dolayısıyla bu fetvalar teorik meselelerden ziyade uygulama esnasında çıkan sorunlarla daha çok ilgilidir. Bu nedenle kendi dönemlerinde önemsenmiş ve mecmualar şeklinde derlenmiş yönetici, müftü, hâkim ve halk için bilgi ve meşruiyet kaynağı olmuşlardır. ${ }^{43}$

38 Serahsi, Mebsut, 22/19; Kâsânî, Bedâiu's-Sanâi, 6/87; Mecelle, Md. 1413.

39 Şeybânî, Ebu Abdullah Muhammed b. Hasen, el-Camiu's-Sagîr, (Şerhini Abdulhay Leknevi'nin yaptığı Nafiu'l-Kebir ile beraber basım), (Beyrut: y.y., 1986), 424; Serahsi, Mebsut, 22/23; Köse, "Ticaret Hukuku Tarih Açısından Mudârebe ve Commenda Ortaklıklarının Etkileșimi Hakkında Bir Deneme”, 171.

40 Serahsi, Mebsut, 22/40; Merğînânî, Hidâye, 3/226; Mecelle, md. 1406, 1414.; İslâm Şirketler Hukuku, 280-281.

41 İbn Kemal, Risâle fî Mesâili'l-Fetâvâ (İstanbul: Süleymaniye Kütüphanesi, Yeni Cami, 685), vr. 224a-b.

42 Ahmet İnanır, “XVI. Yüzyıl Osmanlı Fetvalarında Ahilik” Ondokuz Mayıs Üniversitesi İlahiyat Fakültesi Dergisi, Samsun (2014), Sayı: 36, 104.

43 İbn Kemal, Fetâvâ-yı İbn Kemal, Nuruosmaniye, 1967, vr. 58a; Ebussuûd, Mecmûatü'l-Fetâvâ (İstanbul Müftülüğü Kütüphanesi, 187), vr.142a-b; Fahrettin Atar, "ifftâ Teşkilatının Ortaya Çıkışı”, Marmara Üniversitesi İlahiyat Fakültesi Dergisi, 3 (1985), s. 46; Ahmet İnanır, “İbn Kemal’in Fetvaları Işığında Osmanlı’da İslâm Hukuku”, Doktora Tezi, İstanbul Üniversitesi Sosyal Bilimler Enstitüsü, 2008, s. 64. İbn Kemal, Fetâvâ-yl Kemalpaşazâde der Hakk-ı Kızılbaş, Süleymaniye Kütüphanesi, Esad Ef., 3548, vr. 45a-47b.M. Ertuğrul Düzdağ, Şeyhülislâm Ebussuûd Efendi’nin Fetvaları Işığında 16. Asır Türk Hayatı (İstanbul: Şûle Yayıncılık, 1998), 
Mudârebe ortaklığı da söz konusu fetva literatüründe yer alan meselelerden biridir. Hatta diğer ortaklıklara göre daha çok fetvalara konu olduğu söylenebilir. Bunda söz konusu ortaklığın ihtiyaç sahiplerine kredi sağlama dışında, bizzat ticaretle uğraşma imkânı olmayan kadın ve askerlere sermayelerini işletme imkânı sunmasının önemli rolü vardır. ${ }^{44}$ Ortakların gerek kendi aralarında gerekse piyasayla ilgili çeşitli sorunlar yaşaması ve herkes gibi fetva makamından konuvla ilgili dini ve hukuki çözüm araması söz konusudur. Özellikle doğrudan ticaretle uğrașmavan kimseler kâr ve zarar ortaklığı ile sermavelerini isletirken, kârı sevincle karsılarken mudâribin ișleri ivi gitmevip zarar ettiğinde ise büvük öfke ve ıstırap duymuşlardır. Bu durumda bütün hukuki yolları kullanarak kabahati ișletmecive vüklemeve ve ana sermavelerini kurtarmava çalışmışlardır. Fetva makamı bunların ilk müracaat edecekleri mercilerden biri olmuştur. Zira söz konusu fetva literatürü incelendiğinde fetvaların, sadece teorik hukuki meselelerin değil, aynı zamanda toplumun karşılaştığı ibadetler dâhil hayatın bütün alanlarında ortaya çıkan dini veya hukuki sorunların çözümlenmesi olduğu görülür. Çünkü üretimden tüketime Müslümanların taraf olduğu her türlü iktisadi faaliyet helal ve haram gibi dini değerlerden bağımsız değildir. Hayatın normal akışı içinde karşılaşılan sorunlar da fetvalara konu olabilir. Fakat Osmanlı fetva mecmualarında daha çok hakkında farklı görüşlerin bulunduğu ihtilaflı meselelerin konu edildiği görülür. Dolayısıyla mudârebe de tabiî olarak fetvalara konu olmuştur. Osmanlı şeyhülislam fetvaları ise ilgili meselelerde tercih edilen resmi görüşü yansıtması, halkın ihtiyaçlarına cevap vermesi ve müdevven bir kanun olmadığı dönemlerde klasik fikıh kitapları yanında yargılama faaliyetleri esnasında hâkimlerin yararlanacağı bilgi ve yürürlük kaynağı olması gibi nedenlerle hukukçular ve halk tarafından önemsenmiş ve mecmûalar halinde derlenmiştir. Ancak derlemeler yapilırken çoğu defa bir mecmûanın tek bir şeyhülislâma ait olup-olmamasına dikkat edilmemiş, başka şeyhülislâmların fetvaları da aynı mecmûada yer almıştır. Osmanlı tarihinde görev yapmış 129 şeyhülislamın ancak çok azının fetva mecmuaları yayınlanmıştır. ${ }^{45}$ Bu çalışmada mecmuaların hem resmi tutumu yansıtması hem de sonraki asırlara etki etmeleri yanında mecmûalarının tanınırlı̆̆ı ve ulaşılabilirliği bakımından 16-18. yüzyıllarda öne çıkmış şeyhülislamlar arasında yer alan İbn Kemal (öl. 940/1534), Ebussuûd Efendi (öl. 982/1574) Sun'ullah Efendi (öl. 1021/1612), Feyzullah Efendi (öl. 1115/1703) ve Yenişehirli Abdullah Efendi'nin (öl. 1156/1743) fetvaları esas alınmıştır. Şimdi yüzelliyi aşkın ${ }^{46}$ fetvaya dayalı olarak söz konusu asırlarda mudârebe ortaklığılla ilgili sorunlar kendi içinde kuruluş, sermaye, ortaklar ve ileri sürülen şartlar gibi çeşitli başlıklar altında incelenmeye çalışılacaktır.

173 vd.; Ahmet İnanır, Kanûnî Devrinde Osmanlı'da Hukukî Hayat, (İstanbul: OSAV Yayıncllık, 2011); Şehabettin Tekindağ, “Yeni Kaynak ve Vesîkaların Işı̆̆ı Altında Yavuz Sultan Selim’in İran Seferi”, İÜEFTED. 27/22, (1968), 53-55; Pehlül Düzenli, Osmanlı Hukukçusu Şeyhülislâm Ebussuûd Efendi ve Fetvaları, 145 vd.; Saim Savaş, XVI. Asırda Anadolu'da Alevilik, İstanbul, Vadi Yayıncılık, 2002, s. 138; Mustafa Ekinci, Anadolu Alevîliğinnin Tarihsel Arka Planı (İstanbul: Beyan Yayıncılık, 2002), 167-170; İnanır, “Osmanlı'da İslâm Hukuku", 38.

44 Gedikli, Osmanlı Şirket Kültürü, 53-56, 133-137.

45 Ahmet İnanır, “XVI. Yüzyıl Osmanlı Devleti'nde Fetvanın Yeri ve Günümüz Osmanlı Araştırmaları Bak1mindan Kaynak Değeri”, Osmanlida Fıkıh ve Hukuk, Ed. Süleyman Kaya-Haşim Şahin, (İstanbul: Mahya Yayınları, 2017), 133-149.

46 Bu araştırmada İbn Kemal'de ait sekiz, Ebussuûd Efendi'ye ait seksendört, Sun'ullah Efendi'ye ait altı, Feyzullah Efendi'ye ait yirmi dokuz, Yenişehirli Abdullah Efendi'ye ait kırkbir fetva gözden geçirilmiştir. 


\subsection{Mudâribin Sermayedârın Şartlarına Riâyet Etmemesinden Kaynaklanan Sorunlar}

Mudârebe akdinde mudârib ile sermayedar (rabbü'l-mâl) arasında vekâleti de kapsayan bir emanet ilişkisi vardır. Bu durumda mudârib elindeki ortaklık sermavesi olan sermave (re'sülmal) vedia hükmündedir. Buna göre mudâribin teaddi ve taksiri bulunmadığı sürece sermayeye yönelik olarak hukuka aykırı olmayan tasarruflardan veya korumada kusuru olmaksızın meydana gelen zararlardan dolayı mudâribin hiçbir sorumluluğu yoktur. Bu durum fetvalara yansıdığı kadarıyla mudârib ile rabbü'l-mâl arasında re'sülmalın isletilmesi esnasında farklı tutum gelistirmelerine sebep olmustur. Mudârib daha çok kazanmak için sermavevi riske atacak girișimlerde bulunurken, rabbü'l-mâl ise öncelikle sermavevi zarardan korumava çalıșmaktadır. Bu amaçla mekân, zaman, ticaret çeșidi, satıcı ve müssteri tavini gibi bazı şartlar ileri sürerek mudâribi işletmede sınırlandırmaya çalıştığı görülmektedir.

\subsubsection{Mekân Açısından Takyit}

Fetvalarda rabbü'l-mâlin, sermayeyi işletme yeri konusunda mudâribe bazı sınırlamalar getirdiği görülmektedir. Yapılan sınırlamaların bu dönem Osmanlı ticaretinin şekli ve alanıyla ilgili bazı tespitler yapılmasını mümkün kılmaktadır:

Zeyd ber vech-i mudârebe Amr'dan akçe alıp aldığı metâyı İstanbul'da bey edip fâidesini Amr'a verip İstanbul'dan gayri yere alıp gitmeye Amr'ın rızası olmasa, sonra Zeyd, re's aldığı metâyı ahar yere alıp giderken kimisi helak olup mal-ı mudârebe zayi olsa Amr, Zeyd'e tazmine şer'an kadir olur mu? Beyan buyurub müsab oluna. Cevap: Muhalefet etmiş olacak tazmine kadir olur. (Harrarahû Ahmed). ${ }^{47}$

Zeyd, Amr-1 reîse mudârebeye akçe verip: falan yere sefer eyle âhar yere sefer eyleme deyip nehyeylese Amr memnû olan yere sefer eylese fâide vermemeğe kâdir olur mu? el-Cevab: Men' edicek gasbetmiş olur meğer izin verdi olsa. Ebussuûd. ${ }^{48}$

Zeyd Amr'a Karadeniz'e sefer etmek şartı üzere mudârebeye bir miktar akçe verse Amr Akdeniz'e sefer edip akçe helâk eylese şer’an zamân lâzım gelir mi? el-Cevab: Gelir. Ebussuûd. ${ }^{49}$

Zeyd Amr-1 reîse mudârebeye bir miktar akçe verip Amr mezbûr akçe altı y1l gâhî Akdeniz'e sefer edip her seferde olan fâide Zeyd hissesin verirken bir seferki deryâda helâk olup akçe zâyi oldukda Zeyd "Akdeniz'e sefer etmeğe vermedim" idi deyû taallül edip akçeyi Amr'a ödetmeğe şer’an kâdir olur mu? el-Cevab: Nehyetti ise olur. Ebussuûd. ${ }^{50}$

Zeyd-i mudârib Amr'dan mudârebeye aldı̆̆ı mal İstanbul'dan sana gönderin deyip ba'dehû İslâmbul'a gelip malı Amr'a göndermeyip âhar yere gidip mal deryada helâk olsa Amr, Zeyd'e tazmîne kâdir olur mu? el-Cevab: Olur, Amr kendi dedi ise. Ebussuûd. ${ }^{51}$

\footnotetext{
Komisyon, Mecmûatü'l-fetâvâ (İstanbul: Süleymaniye Kütüphanesi, Şehid Ali Paşa, 2867), vr. 56b.

Ebussuûd, Mecmûatül-fetâvâ (İstanbul Müftülüğü Kütüphanesi, 187), vr. 153a.

Ebussuûd, Mecmûatül-fetâvâ (İstanbul Müftülüğü Kütüphanesi, 187), vr. $150 b$.

Ebussuûd, Mecmûatü'l-fetâvâ (İstanbul Müftülüğü Kütüphanesi, 187), vr. 150a.

Ebussuûd, Mecmûatü'l-fetâvâ (İstanbul Müftülüğü Kütüphanesi, 187), vr. 151a.
} 
Fetvalarda geçen yer isimlerine göre Osmanlı'da mudârebe akdinin en yaygın olarak kullanıldığı alanın İstanbul, İzmir ${ }^{52}$, Mısır ${ }^{53}$, Akdeniz ve Karadeniz havzasını içine alan deniz ticareti olduğu söylenebilir. Zira fetvalarda rabbü'l-mâlin bazen Karadeniz ve bazen de Akdeniz'de ticaret yapmakla ilgili kaydına rastlanmaktadır. Her ne kadar bazı fetvalarda sefer yönü belirtilmemiş olsa da onların da aynı havzada ticaret yaptıkları anlaşılmaktadir.

\subsubsection{Zaman Açısından Sınırlama}

Mudârebe ortaklığı sınırlı bir zaman dilimiyle sınırlandırılabileceği gibi uzun vadeli de kurulabilir. Fetvalarda gemi reislerinin belirlenen seferle yetinmeyip tekrar o sermaye ile sefere çıtıkları görülmektedir. Bu durumda elde edilecek kârın paylaşımında ve sermayenin zâyî olması halinde rabbü'l-mâlın zararının tazmini sorunu gündeme gelmiştir:

Zeyd gemici olan Amr'a mudârebeye akçe verip Amr bir defa sefer edip geldikde Zeyd akçesin vermedin Zeyd izinsiz yine sefere gidip gemi helâk olup akçe zâyi olsa Zeyd Amr'a tazmîne şer'an kâdir olur mu? el-Cevab: Bir defa sefere izin vermiş olmayıcak olur. Ebussuûd. ${ }^{54}$

Zeyd, Amr-1 reîse mudârebeye bir miktar akçe vermiş olsa Amr âhar sefere gittikde Zeyd'den izin almak lâzım olur mu? el-Cevab: İzn-i âmm olıcak olur. Ebussuûd. ${ }^{55}$

Mudâribin rabbü'l-mâlın izni olmadan sefere çıması durumunda hukuken emanet konumunda olan sermayeye ihanet etmiş olacağından elindeki mal mağsûb, mudârib de gâsıb konumuna düssmüs olmaktadır. Ebû Hanîfe ve Ebû Yûsuf a göre gasp fiili, mala vönelik bir eylemle mâlikin zilyedliğini gidermek ve avnı zamanda gâsıbın zilyedliğini tesis etmektir. Hanefiler'in vaptığı bu tanımın ıșığında, kâr vb. gasbedilen malda mevdana gelen artıslarda gasp fiili gerceklesmis savılmaz. Zira bu tür artıslar, malın sahibinin elinden cıkmasından sonra meydana geldiğinden dolavı bunlarda mal sahibinin zilyedliği hiç tahakkuk etmemiștir. Bu sebeple de mal sahibinin zilyedliğinin giderilmesi șartı gerçekleșmemekte, dolavisıyla gasp tahakkuk etmemektedir. Muhtemelen bu hukuki zemin mudâribleri rabbü'l-mâle rağmen re'simâl'i kullanma konusunda cesaretlendirdiği söylenebilir. Zira gasbedilen malda meydana gelen artıșlar mevcutsa iade edilir, değilse ancak gâsıp için bir itlâf sorumluluğu olusabilen durumlarda tazmin vükümlülüğü doğar. Hanefi hukukçusu Serahsî, zivadelerin gasp kapsamına dâhil olmadığını Hanefî hukukçularının genel görüsü olarak kavdederken ${ }^{56}$ Kâsânî, İmam Muhammed'in Ebû Hanîfe ve Ebû Yûsuftan farklı olarak zivadelerin gasp edileceği görüșünde olduğunu belirtmektedir. ${ }^{57}$ Aynı gerekçe bir maldan elde edilen veva elde edilmesi mümkün olan menfaat için de söz konusudur. Zira maddî bir malı (avn) bizzat kullanma veva hukukî semerelerle faydalanma şekli her an gerçekleşen bir olaydır. Diğer bir ifadeyle her anın menfaati o anda

\footnotetext{
Yenişehirli Abdullah Efendi, Behcetü'l- Fetava, 486.

Yenişehirli Abdullah Efendi, Behcetiül- Fetava, 488.

Ebussuûd, Mecmûatü'l-fetâvâ (İstanbul Müftülüğü Kütüphanesi, 187), vr. 153a-b.

Ebussuûd, Mecmûatü'l-fetâvâ (İstanbul Müftülüğü Kütüphanesi, 187), vr. 150a.

Serahsi, Mebsut, 11/54.

Kâsânî, Bedâiu's-Sanâi, 7/142.
} 
meydana gelir ve sona erer. Dolavısıvla zorla el konan mallarda o ana kadar sahibinin elde ettiği menfaat gasp anında sona ermekte, gâsıbın elinde başka bir menfaat meydana gelmektedir. ${ }^{58}$

\subsubsection{Alışveriş Konusundaki Takyit}

Fetvalarda rabbü'l-mâl mudâribin ne alıp satacağıyla ilgili bir sınırlama getirmediği takdirde dahi mudâribin serbestiyet içinde hareket edemeyerek ticari örf ile sınırlandırıldığ1 görülmektedir. Meselâ konfeksiyon işleriyle meşgul bir mudâribin tecrübeli olmadığ1 başka işe girmesi teaddi olarak değerlendirilmektedir:

Zeyd Amr'a mudârebeye bir miktar akçe verip "Buğdaya ve arpaya ver gayrıya verme” dedikde Amr: “Akçeyi pirince verdim zâyi oldu” dedikde zamân lâzım olur mu? elCevab: Lâzımdır. Ebussuûd. ${ }^{59}$

Zeyd, Amr'a mudârebeye bir miktar akçe verip ne metâ alacağın tayin eylemese Amr esir alıp zarar ettikde; "Ben esir al demedim" deyû zararın kabul etmemeğe kâdir olur mu? el-Cevab: Amr'ın san'atı sâir esbâb ticâreti olup satmak asla vâki olmamış ise re'y-i hâkimle olur. Ebussuûd. ${ }^{60}$

Mudâribin re'sümâl ile iş yapmaktan ziyade kendisine nakliye amacıyla gemi satın alması da teaddi olarak değerlendirilmektedir:

Zeyd Amr'dan mudârebeye aldığ1 akçe ile Bekir bir gemi iştirâ edip deryada gemi helâk oldukda Amr Zeyd'e verdiği akçeyi tazmîne kâdir olur mu? el-Cevab: Olur. Ebussuûd. ${ }^{61}$

Zeyd Amr-1 reîse bir miktar metâ bey' edip “Semenini mudârebe tarîkı ile isti’mâl eyle" deyip Amr dahi kavl-i mezbûr üzere isti'mâl edip her sefer ettikçe fayda deyû bir miktar akçe verip ba'dehû sefer ettikde gemi helâk olup mal zâyi olsa şer'an Zeyd, Amr'a tazmîne kâdir olur mu? el-Cevab: Olur. Mudârebe-i mezbûre nâ-meşrûdur. Amma ribh deyip verdiği akçeler asla tutulur. Ebussuûd. ${ }^{62}$

Bu fetvalardan mudârib, mudârebe akdi esnasında hangi iş yapmakla meşgulse sermayenin de bu işle meşgul olması için verildiğine dair ticari bir örf olduğu anlaşılmaktadır. Diğer taraftan da mudâribin işletmek için aldığı sermayeyi alt yapı yatırımı olarak kullanması menedilmektedir. Bu yolla mudâribin elde ettiği yeni sermayeyle bilmediği yeni işlere girişmesinin ve hemen kâr getirmeyecek alt yapı yatırımında kullanmasının önüne geçilmeye çalışıldığı anlaşılmaktadır.

Rabbü'l-mâl peşin ve vadeli satım konusunda mudâribi sınırlandırdığı görülmektedir. Bazen rabbü'l-mâl söz konusu vadenin bitmesini beklemeden mudâribin

\footnotetext{
58 Mehmet Âkif Aydın, “Gasp”, Diyanet İslam Ansiklopedisi (İstanbul: TDV Yay. 1996), 13/387-392.

59 Ebussuûd, Mecmûatü'l-fetâvâ (İstanbul Müftülüğü Kütüphanesi, 187), vr. 153a; Benzer içerikli fetvalar için bk. Feyzullah Efendi, Fetâvâ-yı Feyziyye, haz. Süleyman Kaya (İstanbul: Klasik Yayıncılık, 2009), 336, 2020, 2031 ve 2039 no'lu fetva. (Illkinde mudâribin köle işi yapmasının men edilmekte diğerinde ise susam işi yapilması belirtilmektedir).

60 Ebussuûd, Mecmûatü'l-fetâvâ (İstanbul Müftülüğü Kütüphanesi, 187), vr. 151b; Benzer fetva için bk. Feyzullah Efendi, Fetâvâ-yı Feyziyye, 339, 2036 no'lu fetva.

61 Ebussuûd, Mecmûatü’l-fetâvâ (İstanbul Müftülüğü Kütüphanesi, 187), vr. 150b.

62 Ebussuûd, Mecmûatü'l-fetâvâ (İstanbul Müftülüğü Kütüphanesi, 187), vr. 151b.
} 
kendi malından ana sermave ve kârı tahsil etmeye çalıştığ ${ }^{63}$, bazı mudâriblerin vadeyle ilgili şartlara riayet etmediği anlaşılmaktadır:

Zeyd Amr'a mudârebeye akçe verdikde nakde bey' eyle demiş olup ba'de zamânin akçesin istedikde Amr aldığı metâı vâde ile bey' eylemiş olup Zeyd vâde hulûl ettikde "akçeni alıvereyin" demeğe kâdir olur mu? el-Cevab: İbtidâen akçe henüz nakit iken müşầ olmadan veresiye almaktan nehyetti ise nehiy sahihtir. Amr teaddî eylemişolur. Akçe vermek gerektir. Ebussuûd. ${ }^{64}$

Rabbü'l-mâlin şartlarına riâyet etmemek zarar durumunda mudâriblere tazmin yükümlülüğü yüklese de kâr halinde ise rabbü'l-mâle pay verme yükümlüğü bulunmamaktadır:

Zeyd, Amr'a mudârebe tarikiyle şu kadar akçe verdikten sonra "Meblağ-i mezbûr ile yağ iştirâ eyle" deyu tayin ve tahsis ettikten sonra Amr meblağ-ı mezbur ile yağ iştirâ etmeyip Zeyd'in izinsiz esir iştirâ edip şu kadar faide hâsıl olsa Zeyd ol faidede Amr’a müşârekete kâir olur mu? el-Cevab: Olmaz. ${ }^{65}$

\subsubsection{Taşıma Vasıtaları ve Şahıs Konusundaki Sınırlama}

Rabbü'l-mâlin mudâribe sermayeyi kimin nasıl işleteceği konusunda da bazı sınırlamalar getirdiği görülmektedir. Mudâribin bu şartlara riayet etmemesi teaddi olarak değerlendirilmektedir:

Mâl-i mudârebe isti'mâl eden Zeyd-i rê̂s kendi sefer ettiği gemiyi satıp mal sahibinin icâzeti yoğken âhar kimse gemisiyle seferde mâl-ı mudârebe helâk olsa zamân lâzım olur mu? el-Cevab: Sahibinin emrine muhâlefet edicek olur. Ebussuûd ${ }^{66}$ Bu sûrette Zeyd cümle mâl-ı mudârebeden bir miktarını kendi yoldaşlarından Amr'a mudârebeye vermiş olup Amr dahi onunla metâ alıp gemi gark oldukda zâyi olduğu takdirce sahipler Zeyd'in Amr'a verdiği akçeyi tazmîne şer'an kâdir olur mu? el-Cevab: Olurlar. "İstediğin şekilde işlet” demediler ise. Ebussuûd. ${ }^{67}$

Zeyd Amr-1 reîse mudârebeye bir miktar sermâye verip Amr-1 mezkûr kendisi gitmeyip sermâyeyi gemisi ile Bekir'e teslîm edip sefere gönderse lâkin Zeyd'in izni olmasa Bekir gemisini sürerken gemi gark olup sermâye sermayedara göre Bekir'e vermekten sarîhan nehyetmedi ise mudârebeyi tevkîle ve bidâayı âhara vermeğe kâdir. Ebussuûd. ${ }^{68}$

Mudârib, ilke olarak başkalarını alış-veriş konusunda yetkilendirebilir. Mecelle de bu yetki “âhar kimseyi bey’ ve şirâya tevkîl edebilir. Mal-i mudârebeyi îdâ’ ve ibzâ’ ve rehin ve irtihan ve îcâr ve istîcar edebilir" ${ }^{169}$ şeklinde ifade edilmiştir. Ama rabbü’l-mâl mudâribin maiyetindeki bir kimseyi özellikle belirtip menetmişse bu durumda mudâribin söz konusu şarta uyması gerekir.

63 Feyzullah Efendi, Fetâvâ-yı Feyziyye, 337, 2024 ve 2027 no'lu fetva.

64 Ebussuûd, Mecmûatü'l-fetâvâ (İstanbul Müftülüğü Kütüphanesi, 187), vr. 151a.

65 Yenişehirli Abdullah Efendi, Behcetü'l- Fetava, 486.

66 Ebussuûd, Mecmûatü'l-fetâvâ (İstanbul Müftülüğü Kütüphanesi, 187), vr. 151a.

67 Ebussuûd, Mecmûatü'l-fetâvâ (İstanbul Müftülügü Kütüphanesi, 187), vr. 152a; Benzer bir fetva için bk. Yenişehirli Abdullah Efendi, Behcetü'l- Fetava, 488.

68 Ebussuûd, Mecmûatü'l-fetâvâ (İstanbul Müftülüğü Kütüphanesi, 187), vr. 152a; Benzer bir fetva için bk. Yenişehirli Abdullah Efendi, Behcetü'l-Fetava, 488.

69 Mecelle md. 1414. Fetva ile Mecelle kaidesinin ibarelerinin dahi birebir örtüşmesi dikkat çekicidir. 


\subsection{Re'sümâlin Karz, Muamele yahut Bidâa Olarak Verilip Verilmediğinden Kaynak- lanan Sorunlar}

Mudârebe bir tarafın emek diğer tarafın sermaye ile ortak oldukları bir sözleşmedir. Mudârebede zarar ortaya çıkması halinde özellikle rabbü'l-mâlın ana sermayesini korumak için karz, emanet ve muamele yapmak üzere verdiğine dair bazı iddialarda bulundukları görülmektedir:

\subsubsection{Karz İddiası}

Karz, terim olarak bir kimsenin diğerine, misli olup ancak tüketilerek (istihlak edilmek) faydalanılan bir malı, sonunda mislinin kendisine ödenmek üzere temlik etmesidir. ${ }^{70}$ Hz. Peygamber, Müslümanları karz-1 hasen vermeye teşvik etmiş, karz-1 hasenin sadaka vermekten iki kat daha faziletli olduğunu haber vermiştir. ${ }^{71}$ Mudâriblerin toplumun birikimlerinden karz-1 hasen yoluyla finansman sağlamaya çalışmışlardır. Ancak karz-ı hasendeki vadenin bağlayıcı olmaması yani mukrizin istediği zaman geri isteyebilmesi ve kaybolması halinde tazmin yükümlülüğü, onların bu yöntem ile ihtiyaç duydukları finansmanı sağlamakta zorlandıkları görülmektedir. ${ }^{72}$ Bu sebeple söz konusu sermayeyi karz olarak değil de teaddileri olmadığı takdirde tazmin yükümlülüğü olmayan ve sürenin belirli olduğu mudârebe usulüyle almayı tercih ettikleri anlaşılmaktadır. Özellikle zarar durumunda rabbü'l-mâl ile mudâribin temel ihtilaf noktası haline gelmektedir. Burada rabbü'lmâl ana sermayesini kurtarmak mudârib ise tazmin yükümlülüğünden kaçınmak için uğraşmaktadır:

Zeyd, Amr'dan karz akçe dava edip beyyine ikamet eder olsa, Amr "Mudârebe aldım" diye beyyine ikamet eder olsa, şer'an hangisi evlâdır? Cevap: Beyyine-i karz evlâdır. ${ }^{73}$

Zeyd, Amr'ı reîse mudârebeye virdüğü akçeyi “karz vermişdim” deyu beyyine ikamet idüb Amr "mudarebeye aldım" deyu beyyine ikamet eylese hangisinin beyyinesi evlâdır Cevap: Karz beyyinesi evlâdır ve lehû ufiye anh. ${ }^{74}$

Mudârebe beyyinesi mi evlâdır yoksa karz beyyinesi mi evlâdır? Cevap: Karz beyyinesi evlâdır. ${ }^{75}$

Mudârib yahut rabbü'l-mâl herhangi delil ortaya koyamadığı hallerde karz delilinin kabul edildiği görülmektedir. Zira mudârib rabbü'l-mâlin izniyle sermayeyi kabzettiğine göre rabbü'l-mâl malı teslim ettiğini itiraf etmektedir. Bu durumda mudâribe tazmin davası açabilir:

70 Ayrıntılı bilgi için bk. H. Yunus Apaydın, "Karz", Türkiye Diyanet Vakfi İslam Ansiklopedisi (ìstanbul: TDV Yayınları, 1995), 24: 520-525.

71 İbn Mace, Sadakat, 19.

72 Zeyd Amr'a karz akçe verse ba' dehû Zeyd akçesini isteyip Amr vermeyip Zeyd istedikten sonra Amr, ol akçeyi hizmetlenmesi şer'an helal olur mu? el-Cevap: Helal olmaz. (ibn Kemal, Fetâvâ-yl ibn Kemal, Nuruosmaniye, 1967, vr. 66a, 173a; İbn Kemal, Fetâvâ-yl İbn Kemal, Dârü'l-Mesnevi, 118, vr. 66a).

73 İbn Kemal, Fetâvâ-yı İbn Kemal, Dârü'l-Mesnevi, 118, vr. 80a.

74 Sun'ullah Efendi, Fetâvâ-yı Sun'ullah Efendi (İstanbul: Süleymaniye Yazma Eserler Kütüphanesi, Hüsnü Paşa, 502), 45b; Ebussuûd, Mecmûatül'-fetâvâ (Süleymaniye Kütüphanesi, Esad Ef., 3406), vr. 69b.

75 İbn Kemal, Fetâvâ-yı İbn Kemal (Süleymaniye Kütüphanesi, Nuruosmaniye, 1967), 33a; Ebussuûd, Mecmûatü'l-fetâvâ (Süleymaniye Kütüphanesi, Esad Ef., 3406), vr. 69b. 
Zeyd, Hind'den aldığı mâlı "mudarebeye almış idim” helak oldu deyüb "Hind karz vermișdim" dese beyyineleri olmayacak kavl hangisinindir. ${ }^{76}$

Fakat her iki tarafın delili olduğu takdirde karz delili kabul edilmektedir. Ancak rabbü’l-mâlin karz verdiğine dair delili olmadığı hallerde mudâribin mudârebe olduğuna dair yemini kabul edilir:

Zeyd Amr'a tenhâda bir miktar karz akçe verip ba'de zamânin talep ettikde Amr Zeyd'e: Sen bana akçeyi mudârebeye vermiş idin helâk oldu deyip ikisi dahi beyyineden âciz olıcak hangisinin kavli mûteber olur? el-Cevab: Amr kavli mûteberdir yemîni ile. Amr akçeyi Zeyd'in izniyle kabzettiğine Zeyd mu'terifdir. Amr'in üzerine damân dâvâ eder. Beyyinesi olmayacak münkir olan Amr yemîni ile musaddakdır. Ebussuûd. ${ }^{77}$

Görüldüğü üzere fetvalarda, tarafların sermayeyi alırken teslim tesellüm belgesi alıp almadığı veyahut şahitlerle mahiyetini tespit edip etmediği durumuna göre hüküm verilmektedir. "Delil iddia eden üzerine, yemin inkâr eden üzerine gereklidir" ve "beyyine, zahirin hılafını isbat içindir, yemin aslın bekası içindir."

Bir kimse karz ile elde ettiği şeye malik olur, sadece mukrıza bunun mislini vermekle mükelleftir. Karz verilen para, iade edilmesi gereken bir paradır. Kişi karz olarak aldığı paranın yarısını iade etse diğer yarısını mudârebe akdine sermaye yapamaz. Zira zimmetinde olan re'sümâl ayrıca mudârebe yapılamaz:

Zeyd "Var kâr kesbeyle" deyû Amr'a bir miktar akçe verdikten sonra Amr kâr kesb üzere iken Zeyd zikrolan akçe nıffın Amr'dan aldıktan sonra "Nısfın kullan” fâidesinde müşterek olalım deyip ne kadar Amr-1 mezbûr akçenin nıffın kullanıp nice fâide eylese Zeyd Amr ile fâidede müşterek olur mu? el-Cevab: Olmaz. Evvelâ verdiği “Kendin içün kâr kesb eyle deyû vericek verdiği akçe karz olur. Karz olan akçe zimmetinde olur. Nısfın alıp nısfi zimmetinde iken "Onunla mudârebe amel eyle" demiş olur. Zimmetinde olan akçeyi re'simâl-i mudârebe olmak yoktur. Ribh cümle Amr'ındır. Zeyd'e asl-ı akçenin bakıyyesin verir. Ebussuûd. ${ }^{79}$

Zeyd Amr-1 reîse karz akçe verdikten sonra; neyse (?) mudârebeye olsun dese, Amr râzı olsa ba'dehû akçe zâyi olsa zamân lâzım olur mu? el-Cevab: Akçe zimmetinde iken: "Mudârebeye olsun dedi" ise olur. Daha elinde iken ol mecliste demekle ise olmaz teaddî ve taksir etmeyicek. Ebussuûd. ${ }^{80}$

Bazen rabbü'l-mâl mudârebe diye kâr payı aldığı ortaklıkta mudârib son sefere giderken mudarebe malı karz olsun diyerek ortaklığı bitirmek istediği mal nakde dönmemişse geçerli olmadığı görülmektedir. ${ }^{81}$ Zarar ortaya çıktıktan sonra karz verdiği iddiasinda bulunabilmektedir:

Zeyd Amr'dan mudârebeye beş bin akçe alıp birkaç yıl kullanıp "Fâideden hisse" deyû Amr dört bin akçe verip sonra mâl-i mudârebe helâk olup Amr "Karz verdim idi"

\footnotetext{
Sun'ullah Efendi, Fetâvâ (Hüsnü Paşa, 502), 55a.

77 Ebussuûd, Mecmûatü'l-fetâvâ (İstanbul Müftülüğü Kütüphanesi, 187), vr. 151a.

78 Mecelle, Md. 78.

79 Ebussuûd, Mecmûatü'l-fetâvâ (İstanbul Müftülügü Kütüphanesi, 187), vr. $152 b$.

80 Ebussuûd, Mecmûatü'l-fetâvâ (İstanbul Müftülüğü Kütüphanesi, 187), vr. 152a.

81 Sun'ullah Efendi, Fetâvâ (Hüsnü Paşa, 502), 55a.
} 
deyû beyyine ikâmet edip beş bin akçe talep ettikde Zeyd dahi “Çünki karz verdin muâmelesiz benden bu kadar fâide aldın" deyû verdiği fâideyi Amr'dan almağa kâdir olur mu? elCevab: Olur "ibtidâen karz verdim" der ise. Ebussuûd. ${ }^{82}$

\subsubsection{Muamele İddiası}

Osmanlı Devleti'nde sermavevi ișletme yollarının başında “muamele-i şeriyye” gelmektedir. Bu işlem fikıh literatüründe îne satışı olarak bilinmektedir. Terim olarak îne (ıyne) satışı; genellikle bir kimsenin bir malı belli bir fiyat karşlığında vadeli olarak satıp aynı malı peşin paravla sattığı fiyattan daha ucuza geri satın almasını ifade eder. ${ }^{83}$ Osmanlı fakihleri îne verine özellikle "muâmele" ve "muâmele-i ser'ivye" ismini kullanmavı tercih etmektedir. Muâmele sonucu elde edilen kazanca da meşrû kâr anlamında "ribh-i șer'̂̀" denilmektedir. ${ }^{84}$ Muamele-i şer'iyye, bu asırlarda resmî ölçüler dâhilinde ve herhangi bir borçlanma gibi kayıt tutularak yapılmaktadır. ${ }^{85}$

Fetvalara yansıdığı kadarıyla taraflar arasında sermayenin mudârebe veya muâmele olup olmadığı hususunda ihtilaf edilmekte ve iddialarını delillendirmeye çalışmaktadırlar. Deliller arasında herhangi bir tercih yapılamadı̆̆ı takdirde; sermaye zâyî olmuşsa karz, kâr elde edilmişse mudârebe delilinin tercih edildiği görülmektedir. Aynı hükmün muâmele ve mudârebe delilleriyle ilgili de verildiği görülmektedir. Bu şekilde rabbü'l-mâlın mudâribin kötü niyetli yaklaşımlarından korunmaya çalışıldığı söylenebilir:

Zeyd Amr'a verdiği akçe içün Amr “Zeyd bana ol akçeyi mudârebeye verdi” idi deyû beyyine ikâmet eylese Zeyd "Mezbûr akçeyi Amr'a onun on bire muâmeleye verdim” deyû beyyine ikâmet eylese hangisinin beyyinesi evlâdır? el-Cevab: Akçe zâyi oldu ise karz muâmele beyyinesi evlâdır. Ribh etti ise Amr beyyinesi evlâdır. Ebussuûd. ${ }^{86}$

Zeyd bir mikdar akçesin Amr-1 verese mudârebeye verüb birkaç kerre fâidesin alduği ma'rûf ve mütevâtir iken "karz verdim" deyû beyyinesine amel olunur mu? Beyân buyurulub müsâb oluna. el-Cevab -Allah-u a'lem- Amel olunur beyyine âdile ise. Mâl-1 mudârebe sonradan karz olur. Karz, re'sümâl-i mudârebe olmaz. Ketebehû Ebussuûd elHakîr ufiye anhu ${ }^{87}$

Karz beyyinesi mi evlâdır mudârebe beyyinesi mi evlâdır? el-Cevab: Mal hâlik ise karz beyyinesi evlâdır. Mudârebe elinden etmiş olup rabb-i mâl mudâribe dâvâ edip ribh talep edip hasmı karz dâvâ edip "Ribh cümle benimdir der" ise mudârebe beyyinesi evlâdır. Ebussuûd. ${ }^{88}$

82 Ebussuûd, Mecmûatü'l-fetâvâ (İstanbul Müftülüğü Kütüphanesi, 187), vr. 153b.

83 H. Yunus Apaydın, “Îne”, Türkiye Diyanet Vakfi İslam Ansiklopedisi (İstanbul: TDV Yayınları, 2000), 22: 283; Nezih Kemâl Hammâd, el-Ukûdü'l-mürekkebe fi'l-fikhi'-İslâmiyyi, (Dımeşk: Dâru'l-kalem, ,1325/2004), 19-20.

84 İbn Kemâl, Fetâvâ (Süleymaniye Kütüphanesi, Âşir Ef., 270), vr. 100a; Bilal Aybakan, "Muâmele”, Türkiye Diyanet Vakfi Islam Ansiklopedisi (İstanbul: TDV Yayınları, 2005), 30: 320; Ahmet İnanı, İbn Kemal'in Fetvaları Işığında Osmanlı'da İslam Hukuku (Ankara: Gece Kitaplığı, 2015), 240-241.

85 Vejdi Bilgin, Fakih ve Toplum (İstanbul: İz Yayıncilık, 2003), 152.

86 Ebussuûd, Mecmûatü’l-fetâvâ (İstanbul Müftülüğü Kütüphanesi, 187), vr. 151a.

87 Komisyon, Mecmûatü'l-fetâvâ (Şehid Ali Paşa, 2867), vr. 67a.

88 Ebussuûd, Mecmûatü'l-fetâvâ (İstanbul Müftülüğü Kütüphanesi, 187), vr. 151b. 


\subsubsection{Bidâa İddiası}

Mudarebe ortaklığı çok kâr ettiği hallerde bu defa rabbü'l-mâl sermayeyi bidâa olarak verdiğini iddia edebilmektedir. Böyle olduğuna dair delili olmadığı takdirde mudaribin sözü esas alınır:

Zeyd Amr'dan aldığ 1 şu kadar akçe ile bir müddet ticaret edip onsekizbin akçe faide husulünden sonra Zeyd "Meblağ-1 mezburu faidesi beynimizde münâsafa olmak zere almışdın, faidenin nısfı dokuzbin akçe benim olur" deyu dava, Amr dahi "Ben meblağ-i mezburu sana bidaa tarikiyle vermişdim cümle faide benimdir" deyip ihtilaf üzere olsalar kavil hangisinindir? el-Cevab: Amr'ındır. ${ }^{89}$

\subsection{Sermayenin Tesliminden Kaynaklanan Sorunlar}

Bu dönemde re'sümâlin ve kârın teslimiyle ilgili bazı sorunlar ortaya çıktığı anlaşılmaktadır. Bu konuda mudâribin sermayeyi sermayedara teslim ettiğine dair yemin esas alınmakta, mudâribin adil ve güvenilir olması şart koşulmaktadır:

Zeyd "mudârebe-i, rabbü'l-mâle teslim ettim" dese, rabbü'l-mâl inkâr edecek Zeyd'in kavli yeminle tasdik olunur mu? Cevap: Olunur. ${ }^{90}$

Zeyd Amr'a nice defa tenhâda mudârebeye akçe verip Amr da Zeyd'e tenhâda cemîin teslîm edip ba'de zamânin Zeyd müflis olup Amr'a "Sende mudârebeye akçem vardır" deyû talep edicek Amr teslîmin isbât edemeyip yemîni ile tasdîk olunur mu? el-Cevab: Âdil emîn ise olunur. Ebussuûd. ${ }^{91}$

Mudâribin rabbü'l-mâle kâr olarak verdiği akçeyi yanlışlıkla verdiği gerekçesiyle geri istemesi hukuken gerçekçi bulunmamaktadır:

Zeyd, Amr'la tuttuğu işin akçesinden sehvile bir miktar akçe ziyade verse, haliyen Zeyd ziyade talep eylese şer'an alabilir mi? Cevap: Alınmaz, "bu ribhdir” diye verdiyse. $^{92}$

\subsection{Mudârebenin Kuruluş Sermayesiyle İlgili Sorunlar}

Mudârebede sermaye para cinsinden olmalıdır, para dısında taşınır bir mal (uruz) olması caiz değildir. Hanefilere göre sermaye miktar, cins ve vasıf yönünden belirlenmiş hazır nakit para olmalıdır. ${ }^{93}$ İlk dönemlerde nakit paradan maksat özellikle kullanımdaki dinar ve dirhemdir; ancak İmam Muhammed es-Sevbânî ve geç dönem Hanefî hukukçular buna tedavüldeki bakır paraları ve meskûk olmayan altın ve gümüşü de katmışlardır. ${ }^{94}$ Mecelle'de bu husus şu şekilde maddeleşmiştir:

"Ra'sü'l-malin, sermâye-i şirket olabilecek mal olması şarttır. Binaen-alâ-zâlik, urûz ve akar ile zimem-i nâsda olan alacak, mudârebede ra'sü'l-mal olamaz. Fakat rabbü'l-mal, eğer urûzdan bir şey verip de "bunu sat semeniyle mudârebeten amel et"

\footnotetext{
89 Yenișehirli Abdullah Efendi, Behcetü'l-Fetava, 489.

90 İbn Kemâl, Fetâvâ (Süleymaniye Kütüphanesi, Hacı Mahmut Efendi, 1224), vr. 140a.

91 Ebussuûd, Mecmûatü'l-fetâvâ (İstanbul Müftülüğü Kütüphanesi, 187), vr. 152a.

92 İbn Kemal, Mecmau'l-mesâili'ş-şer'iyyefíl-ulûmi'd-dîniyye (İstanbul Üniversitesi Merkez Kütüphanesi, Nadir Eserler-Türkçe, 6253), vr. 52a.

93 Serahsi, Mebsut, 22/33; Kâsânî, Bedâiu's-Sanâi, 6/83; Mecelle, Md. 1409.

94 Mecelle, Md. 1339, 1340.
} 
dese, mudârib dahi kabul ve kabz ederek ol malı satıp, bedeli olan nukûdu sermâye edip de alış-veriş eylese, mudârebe sahih olur. Kezâlik "falanın zimmetinde alacağım olan şu kadar kuruşu kabz et de mudârebe yolunda kullan" dese ve o dahi kabul etse, sahih olur. ${ }^{95}$

Fetvalarda rabbü'l-mâlin buğday, kendir, bez ve koyun gibi taşınır malların re'sümâl yapmaya çalıştı̆̆ görülmektedir. Bazen mudârib söz konusu malı da kârına satarak sermaye yapabilmektedir. Bu durumda rabbü'l-mâl ondan da kâr istemektedir. ${ }^{96}$ Burada rabbü'l-mâl vekâlet verip mudârebeye kullan demediği takdirde mudârebe akdi kurulmuş olmadığı görülmektedir:

Zeyd Amr'a Mudârebe deyû bahâsın ta'yin edip bir miktar buğday ve kendir verse mudârebe sahîh olur mu? el-Cevab: Amr'a bey' edip semeni mudârebeye isti'mâl et dedi ise olmaz. Tevkîl edip "Bey' eyle semenini mudârebeye isti'mâl eyle” dedi ise olur. Ebussuûd. ${ }^{97}$

Zeyd, Amr-1 rê̂se bir miktar metâ bey' edip “Semenini mudârebe tarîkı ile isti'mâl eyle” deyip Amr dahi kavl-i mezbûr üzere isti'mâl edip her sefer ettikçe fayda deyû bir miktar akçe verip ba'dehû sefer ettikde gemi helâk olup mal zâyi olsa şer'an Zeyd Amr'a tazmîne kâdir olur mu? el-Cevab: Olur. Mudârebe-i mezbûre nâ-meşrûdur. Amma ribh deyip verdiği akçeler asla tutulur. Ebussuûd. ${ }^{98}$

Birkaç nefer celebler, Zeyd'e bir miktar akçe verip "Var, bu akçe ile koyun al benim için İstanbul'a ilet ondan sonra semenini yılına değin kullan” deseler, Zeyd dahi dedikleri gibi koyun alıp götürürken yolda koyunun bazısı kırılsa ziyan celeblere mi olur Zeyd'e mi olur? Cevap: Zeyd'indir.9 ${ }^{99}$

Zeyd Amr'a bir miktar akçe ve dört yüz akçelik bez mudârebeye verip bez Amr'in yedinde helâk olsa bezi tazmîne kâdir olur mu? el-Cevab: Bezi Zeyd Amr'a bey' etti ise olur. Amr'a bey' etmeyip emâneten verip "Sat dahi akçesin mudârebe tarîkı ile kullan dedi” ise olmaz mudârebe-i sahîha. Ebussuûd. ${ }^{100}$

Zeyd Amr'a mudârebeye sekiz yüz akçelik bez verse şer'an mudârebesi sahîh olur mu? el-Cevab: "Bey' edip akçesiyle mudârebe amel eyle” deyû tevkîl edicek olur. Ebussuûd. ${ }^{101}$

Zeyd Amr'a bazı esbâb bey' edip “Dahi akçesi sende dursun mudârebeye kullan” dese mudârebe sahîha olur mu? el-Cevab: Olmaz. Ebussuûd. ${ }^{102}$

Bazı fetvalarda şirket malının mudârebeye verildiği görülmektedir:

Zeyd ile Amr şerîkler olub Zeyd Bekr'e mudârebe ile Amr'a bir mikdar mal verse "mal-1 şirketden verdim" deyû yemîni ile kavline itibar olunur mu? el-Cevab: Olunur.

\footnotetext{
95 Mecelle, Md. 1409.

96 Feyzullah Efendi, Fetâvâ-yı Feyziyye, 338, 2032 no'lu fetva.

97 Ebussuûd, Mecmûatü'l-fetâvâ (İstanbul Müftülüğü Kütüphanesi, 187), vr. 150a; Benzer fetva için bk. Sun'ullah Efendi, Fetâvâ (Hüsnü Paşa, 502), 54b; Feyzullah Efendi, Fetâvâ-yı Feyziyye, 335.

98 Ebussuûd, Mecmûatü'l-fetâvâ (İstanbul Müftülüğü Kütüphanesi, 187), vr. 151b.

99 İbn Kemâl, Fetâvâ (Süleymaniye Kütüphanesi, Âşir Ef., 270, vr. 116b.

100 Ebussuûd, Mecmûatül-fetâvâ (İstanbul Müftülüğü Kütüphanesi, 187), vr. 151b-152a.

101 Ebussuûd, Mecmûatü'l-fetâvâ (İstanbul Müftülüğü Kütüphanesi, 187), vr. 151b.

102 Ebussuûd, Mecmûatü'l-fetâvâ (İstanbul Müftülüğü Kütüphanesi, 187), vr. 151b.
} 
Ehad-i şerîkeyn re's-i mal-i şirketden bazını mudârebeye vermeğe kâdirdir. Ebussuud. ${ }^{103}$ Cevab: Ehad-i şerîkeyn memlûki kitabete kesmeğe kâdirdir. Ebussuud. ${ }^{104}$

Zeyd karındaşı Amr ile şirket-i inan ile şerîkler olub Zeyd'in izni yok iken re's-i malden bazını Amr âhar mudârebeye vermeğe kâdir olur mu? el-Cevab: Nehy etmedi ise olur. Ebussuud. Bu sûretde Amr re's-i malla bir cariye satun alub Zeyd izninsiz firaş câriyesi edüb bir yıl mikdarı tasarruf ettikden sonra câriye fevt olsa Zeyd hissesin Amr'a tazmine kâdir olur mu? el-Cevab: Olur. Ebussuud. ${ }^{105}$

\subsection{Mudâribin de Sermaye Katma İddiası}

Mudârebe sermaye bir taraftan emek bir taraftan olmak üzere kurulan bir ortaklıktır. Dolayısıyla mudâribin sermaye katması söz konusu değildir. Ancak ne var ki bazen kendi öz sermayesini de katarak işlem yapabilmekte ya da kârdan daha fazla pay alabilmek için böyle iddialarda bulunabilmektedir. Bu durum ya mevcut sermayenin işletme esnasında yetersiz kalmasından ${ }^{106}$ ya da mudâribin muhtemel kârlı ticarette kendi sermayesini kullanmak istemesinden kaynaklanmaktadır. Nitekim Mecelle'de "Mudârib, kendi malıyla mal-i mudârebeyi karıştırdığ sûrette, hâsl olan ribhi, sermâyelerin mikdarına göre taksim eder" denilmektedir. Yani, kendi sermâyesinin fâidesini kendisi alır. Ve mal-i mudârebenin fâidesi rabbü'l-mal ile beynlerinde şart ettikleri vechile taksim olunur ${ }^{107}$ şeklinde ifade edilmektedir. Bu durum mudârebe akdinin kuruluş amacına uygun olmadığından mudâribin bu tür iddiaları fetvalarda sınırlı şartlarda kabul edildiği anlaşılmaktadır:

Zeyd Amr'a mudârebeye bir miktar altın verip Amr dahi altını alıp metâ alıp bey' ettikten sonra Amr "Bir miktar altın ben dahi kattım" dese şer'an yemîni ile tasdîk olunur mu? el-Cevab: "Aldığı metâ cümlesi mâl-i mudârebe ile alınmışdır" deyû ikrâr etmedi ise "Bu metâda benim malım ile alınmış şu miktar kumaş vardır" dese sözü makbûldür. İkrâr etti ise makbûl değildir. Eğer mâl-i mudârebeye halt etti ise me'zûn ise câizdir. Mâl-i mudârebeden ribhinin kendi hissesini ve kendi mal ribhini ve aslını alır. Me'zûn değil ise mudârebeyi zâmin olur metâ1 cümle kendinin. Ebussuûd. ${ }^{108}$

Zeyd Amr'a mudârebeye bir miktar akçe verip ba'de zamânin: "Getir taksim edelim" dedikde Amr "Bu elimde olan mâl-i mudârebeye ben dahi şu miktar akçe kattım" dese yemîni ile tasdîk olunur mu? el-Cevab: Bilfiil malda ribh-i vâfir görünüp "Şu miktarını malımda ben kattım bâkîsi ribhdir" deyû yemîn ederse zammettiği yemîni ile olur (alır??). Amma ribh Zeyd'in Amr'a verdiği mâl-i mudârebe ribhi olmak üzere yine kısmet olunur. Kendi malından akçe kattığına beyyinesiz onun ribhini alımaz. Ebussuûd. ${ }^{109}$

\footnotetext{
103 Ebussuûd, Mecmûatü'l-fetâvâ (İstanbul Müftülüğü Kütüphanesi, 187), vr. 153a.

104 Ebussuûd, Mecmûatü'l-fetâvâ (İstanbul Müftülüğü Kütüphanesi, 187), vr. 85a, 153a.

105 Ebussuûd, Mecmûatü'l-fetâvâ (İstanbul Müftülüğü Kütüphanesi, 187), vr. 84b; Yenişehirli Abdullah Efendi, Behcetü'l-Fetava, 486.

${ }^{106}$ Mudâribin nakliye parasını kendinden ödediği fetva için bk. Feyzullah Efendi, Fetâvâ-yı Feyziyye, 337, 2021 no'lu fetva.

107 Mecelle, Md. 1417.

108 Ebussuûd, Mecmûatü'l-fetâvâ (İstanbul Müftülüğü Kütüphanesi, 187), vr. 153a.

109 Ebussuûd, Mecmûatü'l-fetâvâ (İstanbul Müftülüğü Kütüphanesi, 187), vr. 152b.
} 
Fetvalardan anlaşıldığı kadarıyla mudâribin sermaye kattı̆̆ı iddiası şu şartlarda kabul edilebilir: Birincisi rabbü'l-mâl tarafından izin verilmiş olmalıdır. İzin verilmeden mudârebeye mal kattığı takdirde yemini tasdik edilmez ve rabbü'l-mâlin verdiği mudârebe sermayesini tazmin etmesi gerekir, mevcut mallar ise kendisinde kalır. İkincisi aldığı ticari ürünlerin mudârebe malı olduğunu ikrar etmiş olmamalıdır. Zira ikrar ettikten sonra kendi malını kattığı iddiaları kabul edilmez. Üçüncüsü ise bu konuda bir örfün olması gerekir. ${ }^{110}$

Mudâribin rabbü'l-mâlin bilgisi dâhilinde sermayeyi kendi malına katıp işlettiği esnada vefat etmesi halinde mevcut malın alacaklılar arasında nasıl taksim edileceği sorun olmaktadır. Burada rabbü’l-mâlin hakkı korunarak öncelikle mudârebe malının ayrı tutulmaya çalışıldığı görülmektedir. Mudârebe sermayesini mevcut malın karşılamadığı durumlarda mudârib mudârebe malını beyan etmeden ölmüşse öncelikle mevcut maldan re'sümâlin tazmin edileceği, mirasçıların hissedar olamadığı anlaşılmaktadır.

Zeyd'in yedindeki mâl-i mudârebe kendi malına halt edip metâa verdikde sonra metâ bey' olunmadın fevt olsa cümle metâ taksîm-i guremâ olunur mu yoksa mâl-i mudârebe miktarı mukaddemâ ayrıldıktan sonra kalanı guremâ olunur mu? el-Cevab: Sâhib-i mal halta izin vericek evvelâ mâl-i mudârebe ifrâz olunur. Ebussuûd. ${ }^{111} \mathrm{Bu}$ sûrette yedi bin akçe müteveffânın olup hâliyen cümle terikesinden yedi bin akçe bulunsa nısfını vereseye verip nısfinı alıkomağa kâdir olur mu? el-Cevab: Olmazlar. Amr mâl-i mudârebe beyân etmeden mücehhelât?? fevt olmak ile kendi malından zamân lâzımdır. Ebussuûd. ${ }^{112}$

Zeyd Amr'a mudârebeye akçe verip Amr kendi akçesine halt edip bir iki yol sefer edip hâsıl olan faydayı pay ettikde Zeyd'e hisse vermemeğe kâdir olur mu? el-Cevab: Olur gâsıbdır. Ebussuûd. ${ }^{113}$

\subsection{Mudâribin Sermayeyi Teslimle İlgili Karşlaştı̆̆1 Sorunlar}

Mutlak mudârebede belirli bir süre ta'yini yoktur. Fakat taraflar süreyle ilgili bazı sınırlamalar getirerek mudârebeyi mukayyed hale getirebilir. Dolayısıyla kısa süreliğine mudârebe ortaklığı kurulabildiği gibi uzun süreli de olabilir. Bu durumda mudarebe mal1nın teslim ve tesellüm ile ilgili sorunlar çıkmaktadır:

Zeyd-i müteveffânın veresesi Amr'da olan mâl-ı mudarebeyi taleb itdikte Amr hal-i hayatında Zeyd'e teslim etmiş idim dese yemin-i ile tasdik olunur mu? el-Cevab: Asıl malda tasdik olunur ve lehû ufiye anh. ${ }^{114}$

Uzun süreli mudârebede rabbü'l-mâl kendi veresesine değil de mudâribe kendisi öldükten sonra malının 1/3 dağıtması konusunda vasiyette bulunduğu iddia edilmektedir. Zira İslam miras hukukunda kişi malının $1 / 3$ vasiyet edebilir. Fetvada mudâribin bu iddiası ancak güvenilir bir kimse olduğu takdirde kabul edileceği ifade edilmektedir.

110 Yenişehirli Abdullah Efendi, Behcetü'l- Fetava, 487.

111 Ebussuûd, Mecmûatü'l-fetâvâ (İstanbul Müftülüğü Kütüphanesi, 187), vr. 152b.

112 Ebussuûd, Mecmûatü'l-fetâvâ (İstanbul Müftülüğü Kütüphanesi, 187), vr. 152a.

113 Ebussuûd, Mecmûatü'l-fetâvâ (İstanbul Müftülüğü Kütüphanesi, 187), vr. 153a.

114 Sun'ullah Efendi, Fetâvâ (Hüsnü Paşa, 502), 54b; Benzer fetva için bk. Sun'ullah Efendi, Fetâvâ (Hüsnü Paşa, 502), 55a. 
Zeyd "Ben ölürsem” deyû sülüs malımı fukaraya tasadduk ile Amr'ı vasi eylese Amr dahî kadı verese ma'rifeti yok iken "Zeyd'in mudârebede olan yigirmi bin akçesinde beşbin akçe alub fukaraya tasadduk eyledim” demesi mesmu olur mu? el-Cevab: Amr emin ve salih ve mütedeyyin kimesne olub Zeyd'in vech-i meşruh üzere vasiyyet edüb kendisi vasiy nasb edüb kimesne müşaveresinsiz tasadduk eyle deyû tefviz etdügini beyyine-i adile ile sabit olursa yeminle tasdîk olunur. Ebussuûd. ${ }^{115}$

Rabbü'l-mâl, ana sermayeyi geri almak için kârından vaz geçer gibi yaptı̆̆ı ardından da kârını tahsil etmek için uğraştığı görülmektedir:

Zeyd Amr'a mudârebeye akçe verip Amr'a geldikde akçe inkâr eder deyû havfinden "Fâidesinden ferâgat ettim" deyip akçesin aldıktan sonra fâidesin dahi almağa kâdir olur mu? el-Cevab: Fâide henüz aslından ifrâz olunmamış ise olur. Ebussuûd. ${ }^{116}$

Mudâribin teaddisi olmaksızın meydana gelen zararı tazmin etme yükümlülüğü olduğunu bilmeksizin rabbü'l-mâle yapmış olduğu re'sümâl ödemesini teaddisi olmadı̆̆ takdirde zarar ettiği kadarıyla geri aldığı görülmektedir:

Zeyd Amr'dan mudârebeye aldığı Zeyd'in teaddî ve taksiri olmadan helâk oldukda Zeyd zamân lâzım olmadığına vâkıf olmamağın Amr'a bir miktar akçe verip bâkî talebinden ibrâ eyledikten sonra ahvâle vâkıf olıcak verdiği akçeyi talep edip Zeyd'den almağa kâdir olur mu? el-Cevab: Olur sebeb-i zamân itiraf etmedi ise eğer teaddîden eğer taksirden. Ebussuûd. ${ }^{117}$

Zeyd Amr'a bir sene (?) mudârebeye bir mikdar akçe verüb Amr her seferinde Zeyd'e kâr (?) verüb sonra Amr'ın kimi sefere gelüb helâk olsa Zeyd, Amr'dan akçesini tazmîne kâdir olur mu? Beyân buyurulub müsâb oluna. el-Cevab-Allah-u a'lem- : Olmaz. Teaddi ve taksîr etti ise. Ketebehû Ebussuûd el-hakîr ufiye anhu. ${ }^{118}$

Zeyd-i reîs bazı kimesnelerden mudârebeye mâl alub deryâya sefer edüb seferde iken Amr'a bir mikdar mal verüb fevt olub Zeyd'in kimesnede olan esîrleri dahi Bekr kabz edüb bekledikde rabbü'-mâl olanlardan Bişr ile verese-i Zeyd Bekir'den mâl-1 mezbûri ve esîrleri taleb edüb "Bekr ben almadım" deyû cidden inkâr edicek mezbûrlar mâlı ve esîrleri Bekr'in kab ettiğini isbât edüb hükm-i hâkim müteallık oldukdan sonra dönüb akçe zâyi olub esîrler helâk oldu dedügüne i'tibâr olunur mu? Beyân buyurulub müsâb oluna. el-Cevab-Allah-u a'lem- : Olunmaz. Öyle idügi ma'rûf ve mütevâtir ise Bekr esîrleri gasben almış olıcak. Ketebehû Ebussuûd el-hakîr ufiye anhu. $^{119}$

Rabbü'l-mâl olan Zeyd mudâribi Amr'a “Aldığın on bin filoriye () al deyip ol dahi metâı on bin filoriye alıp âhar şehire iletip sattıkda iki bin filori kâr (?) etse Zeyd on iki binden ziyâdesin Amr'dan almağa kâdir olur mu? el-Cevab: Hissesini tamam alır. Kavl-i mezbûr ile mudârebe akdi bozulup bey' münakid olmaz. Ebussuûd. ${ }^{120}$

\footnotetext{
115 Ebussuûd, Mecmûatü'l-fetâvâ (İstanbul Müftülüğü Kütüphanesi, 187), vr. 212a.

116 Ebussuûd, Mecmûatü'l-fetâvâ (İstanbul Müftülüğü Kütüphanesi, 187), vr. 152b.

117 Ebussuûd, Mecmûatü'l-fetâvâ (İstanbul Müftülüğü Kütüphanesi, 187), vr. 150b.

${ }^{118}$ Komisyon, Mecmûatü'l-fetâvâ (Şehid Ali Paşa, 2867) vr. 51a; Benzer fetva için bk. Sun'ullah Efendi, Fetâvâa (Hüsnü Paşa, 502), 54b-55a.

119 Komisyon, Mecmûatü'l-fetâvâ (Şehid Ali Paşa, 2867) vr. 78b.

${ }^{120}$ Ebussuûd, Mecmûatü'l-fetâvâ (İstanbul Müftülüğü Kütüphanesi, 187), vr. 151b.
} 


\subsection{Re'sümâlin Zarar Etmesi ve Zavi Olmasıvla İlgili Sorunlar}

Ticarette kâr ve zarar kardestir; bazen kâr, bazen de zarar edilir. Bu asırlarda mudârebevle ilgili en cok sorulan konuların basında zarar ve zivan konuları geldiği görülmektedir. Konuyla ilgili fetvalar mudâribin kötü nivetli tutumundan, pivasa sartlarından ve tabiî afet vb. olumsuz sartlardan kavnaklanan zararlar seklinde tasnif edilerek değerlendirilmeve calısılacaktır. Bu savede söz konusu asırlarda zararın kaynaklandığı iktisadi şartları da tespit etmek mümkündür.

\subsubsection{Mudâribin İhmal ve Kötü Niyetle Yaptığı İşlemlerden Kaynaklanan Zararlar}

Mudârebe akdinde, rabbü'l-mâl ile mudârib arasında münasebet emanet ilişkisi olup ortaklık sermavesi olan re'sümâl mudâribin elinde vedia hükmündedir. Dolayısıyla

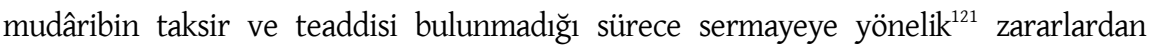
mudâribin hiçbir sorumluluğu yoktur:

Zeyd Amr'a mudârebeye verdiği akçeyi talep ettikde "Zikrolan akçe ile esbâbı almağa varıp akçe koynumdan çıkarıp dizim üzerine komuş idim. Unutmuşum akçe düşüp zâyi olmuş" dese Amr'a zamân lâzım olur mu? el-Cevab: Olur. Ebussuûd. ${ }^{122}$

Zeyd, Amr'a mudârebeye üç bin akçe verip ol akçe ile alıp araba ile getirirken araba ufanıp dökülse zamân lâzım olur mu? el-Cevab: Teaddi ve taksirsiz dökülmek olmaz. Ebussuûd. ${ }^{123}$

Zeyd mudârebeye verdiği akçe Amr dahi Bekir kullanmağa verip akçe Bekir'de zâyi olsa Amr'a zamân lâzım olur mu? el-Cevab: Olur. Ebussuûd. ${ }^{124}$

Görüldügü üzere fetvalarda mudâribin rabbü'l-mâlden izinsiz re'sümâli üçüncü kişilere vermesinden, onu korumadaki ihmalinden ve hayatın tabii akışına ters gerekçelerle zâyî olduğu iddiaları taksir ve teaddi olarak değerlendirilerek mudâribin tazmin etmesi gerektiği ifade edilmiştir:

Zeyd-i reîs kul edüb Amr'ın yüz fuci balını gemisine yükledürüb İstanbul'a getürüb çıkarken bir fiçı bal deryaya düşüb zayi olsa Zeyd'e zamân lâzım olur mu? el-Cevab: Olur. Ebussuud. ${ }^{125}$

\subsubsection{Olumsuz Fizikî Şartlardan Kaynaklanan Zararlar}

Mudârebe akdinde zararlar bazen de mudâribin tasarrufu dışındaki nedenlerden dolayı meydana gelebilmektedir. Fetvalardan anlaşıldığı kadarıyla bu dönemde mudârebe akdini kullananların başında kaptanlar olduğu anlaşılmaktadır. ${ }^{126}$ Bunların deniz aşırı ticaret yaptıkları ve zaman zaman da olumsuz hava şartları sebebiyle gemilerinin yan yattığı ve denize battığı ve bu yüzden mudârebe malının zâyî olduğu görülmektedir:

Zeyd bir gemiye reîs olan Amr'a fâidesini tansîf olmak üzerine mudârebeye dört bin akçe verüb şart olunduğu üzre tasarruf olunur iken gemi yanlanub cümle mal helâk olsa

\footnotetext{
${ }^{121}$ Feyzullah Efendi, Fetâvâ-yı Feyziyye, 338, 2029-2030 no'lu fetva.

122 Ebussuûd, Mecmûatü'l-fetâvâ (İstanbul Müftülüğü Kütüphanesi, 187), vr. 153b.

123 Ebussuûd, Mecmûatü'l-fetâvâ (İstanbul Müftülüğü Kütüphanesi, 187), vr. 153a.

124 Ebussuûd, Mecmûatü'l-fetâvâ (İstanbul Müftülüğü Kütüphanesi, 187), vr. 152a.

125 Ebussuûd, Mecmûatü'l-fetâvâ (İstanbul Müftülüğü Kütüphanesi, 187), vr. 171b.

126 Yenișehirli Abdullah Efendi, Behcetü'l- Fetava, 490.
} 
şer'an Amr'a zamân lâzım olur mu? Beyân buyurulub müsâb oluna. el-Cevab -Allah-u a'lem- : Asla teaddi ve taksîr etmedi ise lâzım olmaz. Ketebehû Ebussuûd el-hakîr ufiye anhu. ${ }^{127}$

Zeyd-i reîs birkaç kimesnelerden mudârebe aldığı akçeleri yok iken halt edip birkaç yıl kullanıp faydasın verdikten sonra ittifâk bir seferde Zeyd'in gemi gark olup mâl-i mudârebe ile aldığı metâın cümlesi zâyi olsa şer'an Zeyd'e zamân lâzım olur mu? el-Cevab: Olur amma fayda deyû verdiği bile mahsûb olur. Ebussuûd. ${ }^{128}$

Zeyd, Amr'a mudârebeye akçe verip Amr dahi isti'mâl ettiği rızkı ve esbâbı gemiden getirttirip kendi gitmek şartı üzere kabul etse Zeyd de râzı olup gemiye(?) yükletip âhar şehre gitse gemi gark olduğu takdirce Amr tazmîne kâdir olur mu? el-Cevab: Teaddî ve taksir ve muhalefet etmeyicek olmaz. Ebussuûd. ${ }^{129}$

Fetvalarda, mudâribin kendi kusur ve teaddisi olmadığı takdirde tazmin sorumluluğu bulunmadığı görülmektedir. ${ }^{130}$ Ancak kendi zararını bertaraf etmek için mudârebe malına yönelik taksiri tazminat kapsamında değerlendirilir, kâr diye aldığı da mudârebe sermayesine dâhil edilmektedir:

Zeyd-i reis gemisi helaka müşrif oldukda Amr Bekr'in meta'larını gemi kurtarmak içün mezbûrler izinsiz deryaya döküb kurtuldukdukda meta'ların taleb edüb Zeyd'e tazmine kâdir olur mu? el-Cevab: Olurlar. Ebussuud. ${ }^{131}$

Zeyd-i reîs gemisinden sandıkla olan mâl-i mudârebeyi gemi helâk olmak sadedinde iken almayıp ancak fâidesin alıp suâl olundukda "Aslı çıkarayım deyû havfettim ve hem sandık ile çıkar(?) ettim” deyû cevap vermekle mal sahibinin mutâlebesinden berî olur mu? el-Cevab: Olmaz. İhtiyârı ile komak teaddîdir. Amma ribhdir deyû çıkardığı asla tutulur. Ebussuûd. ${ }^{132}$

Zeyd-i reîse diyârından bazı kimseler mudârebe ile akçe verip Zeyd gemisin yükletip İstanbul'a gelip metâın bey' edip ba'dehû ol gemiyi bey' edip akçesi ile iki gemi alıp ol gemiyi de yükletip giderken Zeyd cemî yoldaşları ile deryâda gark olduktan sonra Zeyd'e mudârebe ile akçe veren kimesneler muhallefâtından almağa kâdir olur mu? el-Cevab: Asla teaddî ve taksir ve akçe sahiplerinin rıâlarına muhâlefet etmedi ise olmaz. Ebussuûd. ${ }^{133}$

Batan gemiden eşya kurtarma konusunda da mudâribin sözü esas alınır ancak eşya kurtardığına dair delil bulunması halinde hainlik ettiği kabul edilerek re'sümâli tazmin etmesi gerekmektedir:

Zeyd-i reîsin gemisi helâk olup sermâye sahipleri Zeyd'e "Gemiden nesne halâs etmedin mi?" dediklerinde Zeyd “Asla nesne halâs etmedim” deyip ba'dehû bazı metâ halâs edip sattığı zâhir ve sâbit olsa hıyâneti zâhir olmuş olur mu? el-Cevab: Olur. Ebussuûd. ${ }^{134}$

\footnotetext{
${ }^{127}$ Komisyon, Mecmûatü'l-fetâvâ (Şehid Ali Paşa, 2867), vr. 75b.

${ }^{128}$ Ebussuûd, Mecmûatü'l-fetâvâ (İstanbul Müftülüğü Kütüphanesi, 187), vr. 152a.

129 Ebussuûd, Mecmûatü'l-fetâvâ (İstanbul Müftülüğü Kütüphanesi, 187), vr. 151a.

130 Balığın bozulmasıyla ilgili bir fetva için bk. Yenişehirli Abdullah Efendi, Behcetü’l- Fetava, 487.

131 Ebussuûd, Mecmûatü'l-fetâvâ (İstanbul Müftülüğü Kütüphanesi, 187), vr. 171b-172a.

132 Ebussuûd, Mecmûatü'l-fetâvâ (İstanbul Müftülüğü Kütüphanesi, 187), vr. 153b.

133 Ebussuûd, Mecmûatü'l-fetâvâ (İstanbul Müftülüğü Kütüphanesi, 187), vr. 153a.

134 Ebussû̂d, Mecmûatü'l-fetâvâ (İstanbul Müftülüğü Kütüphanesi, 187), vr. 150a-b.
} 
Bazen de çıkan yangınlar mudârebe ortaklarının zarar etmesine neden olmaktadır. Rabbü'l-mâl mudâribden re'sümâli istediği halde muhalefet edip vermemesi taksir kapsaminda değerlendirilmektedir:

Zeyd Amr-1 bakkala mudârebeye üç bin akçe verip ba'dehû "Mudârebeden ferâgat ettim. Akçe ver." deyip Amr bin akçesin verip iki binin dahi vermek üzere iken ittifâk dükkân yanıp iki bin akçe bile yansa zamân lâzım olur mu? el-Cevab: Muhâlefet edip vermedi ise olur. Ebussuûd. ${ }^{135}$

\subsubsection{Güvenlik Sorunlarından Kaynaklanan Zararlar}

Hırsızların yol keserek mudârib-i katledip malını gasp ettikleri durumlar da olmuştur:

Zeyd Amr'dan mudârebe tarikiyle aldığı akçeyi ibtidâen metâa bozup ba'dehû metâ ile ticaret için âhar diyara sefer ettikte yolda Zeyd'i haramîler katledip metâı gâret eyleseler Zeyd'in terekesinden damân lazım olur mu? el-Cevab: Olmaz. ${ }^{136}$

\subsubsection{Piyasa Şartlarından Kaynaklanan Zararlar}

Piyasa şartları bazen ortakların arzu ettiği gibi gerçekleşmez. Çoğu kere evdeki hesap çarşıya uymaz. Kâr edeyim derken zarar edilebilir. Bu durumda mudâribin taksir ve teaddisi olup olmadığına bakılır:

Zeyd Amr'dan mudârebeye ile bir miktar akçe aldıktan sonra teaddî ve taksirsiz ziyân eylese sonra ziyânı Amr'a çektirmeğe kâdir olur mu? el-Cevab: Sebeb-i zamân mu’terif oldu ise olmaz. Ebussuûd. ${ }^{137}$

Sermaye sahipleri ilk girişimde zarar hâsıl olduğu takdirde mudâribe zararı yükleyerek ortaklıktan ayrılmaya çalıştıkları görülmektedir:

Zeyd Amr'dan mudârebe tarikiyle aldığı akçeyi ibtidâen i'mal ettikde "Bilâ-teaddî asl-i mala zarar terettüb eti" deyu dava ve Amr "Zarar etmeyip şu kadar faid hâsıla oldu" deyu dava edip ba'dehû Zeyd re's-i malı tamamen Amr'a vermek üzere Amr ile sulh olsa sulh-i mezbur sahih olur mu? el-Cevab: Olmaz. ${ }^{138}$

Mudârib kâr getirdiğinde nerede ticaret yaptığı sorun olmazken, zarar ettiklerinde ise mudâribin yetkisini aşarak izin vermedikleri yerlere gittiğini iddia edebilmektedir:

Zeyd-i reîs Amr'dan bir miktar mudârebeye aldı̆̆ı akçe ile deryaya nice defa sefer edip Amr'a faydasın verip Amr-1 mezbûr Zeyd'in ne tarafa olursa gittiğin kabûl ederken bir yerde dahi gittikde gemi helâk olup mal zâyi olsa "Ben sana ol cânibe gitmeğe icâzet vermedim” idi deyû Amr Zeyd'den akçesin talebe kâdir olur mu? el-Cevab: Olmaz. İzn-i mutlak kifâyet eder. Ebussuûd. ${ }^{139}$

Söz konusu asırlarda kölelik müessesi mevcuttur. Harplerde alınan esirlerin bir kısmı bağ ve bahçede köle olarak çalıştırılmaktadır. Ancak bu dönemlerde kölelerin kaçması öne çıkan hukuki sorunlardan biridir. Mudarib rabbü'l-mâle re'sümâl ile köle

135 Ebussuûd, Mecmûatü’-fetâvâ (İstanbul Müftülüğü Kütüphanesi, 187), vr. 153b.

136 Feyzullah Efendi, Fetâvâ-yı Feyziyye, 335.

137 Ebussuûd, Mecmûatü'l-fetâvâ (İstanbul Müftülüğü Kütüphanesi, 187), vr. 153a; Benzer bir fetva için bk. Yenişehirli Abdullah Efendi, Behcetü'l- Fetava, 489.

138 Yenişehirli Abdullah Efendi, Behcetü'l-Fetava, 489.

139 Ebussuûd, Mecmûatü'l-fetâvâ (İstanbul Müftülüğü Kütüphanesi, 187), vr. 150a. 
alıp rabbü'l-mâlin işinde çalıştırdığı esnada kölenin kaçması taraflar arasında bazı hukuki sorunlara sebep olduğu anlaşılmaktadır. Burada mudâribin köleyi mudârebe için mi yoksa kendisi için mi aldığı sorunu ortaya çıkmaktadır. Kendisi için aldığı takdirde zarar mudârebe sermayesini etkilemez, mudârebe için alınmışsa mudâribin teaddisi olmadığından tazmin yükümlülüğü olmaz:

Zeyd Amr'dan mudârebeye aldığı altı bin akçenin iki bin akçesine bir kul aldıkda Amr'ın talebiyle Zeyd kulu Amr'ın bağında hizmete gönderip kul Amr'ın bağında hizmette iken ibâk eylese Zeyd, kulun kıymetini asl-i mâldan aşağı vermeye kâdir olur mu? el-Cevab: Mudârebe içün alınmış olup Amr'ın hizmetinde iken Zeyd'in dahli olmadan ibâk edicek zamân lâzım olmaz ki Amr Zeyd'den nesne almağa kâdir ola. Eğer Zeyd kulu mudârebe içün almayıp kendi içün aldı ise kul Amr'ın teaddîsi ile olmadan ibâk edicek Amr'a zamân yoktur. Mâl-i mudârebe tamam olur. Ebussuûd. ${ }^{140}$

Mudârib re'sümâli işletirken yanında elemanlar çalıştırmaktadır. Yanındakilerin Mudârebe sermayesini alıp kaçması durumunda mudâribin tazmin edip etmediği fetvalara konu olmaktadır:

Zeyd Amr-1 reîse mudârebeye bir miktar akçe verip Amr dahi gemisinden olan yoldaşlarından Bekir'e verip "Bir miktar metâ iştirâ eyle" dedikde Bekir gâib olup gelmese Zeyd Amr-1 mezbûra akçeyi tazmîne kâdir olur mu? el-Cevab: Bekir hıyanetle ma'rûf ise olur. Emânet ile meşhûr ise olmaz. Ebussuûd. ${ }^{141}$

Bu durumda çalışanın güvenilir olup olmadığa bakılır. Güvenilirse tazmin gerekmez, değil ise mudâribin kötü niyetli olduğuna hükmedilir.

Mudârib re'sümâli işletirken piyasa şartları gereği paranın tedavülden kalktığı durumlarda olmaktadır. ${ }^{142}$ Bazen malın peşin satılamayıp vadeli satılması rabbü’l-mâl için peşin isteme hakkı vermediği görülmektedir.

Zeyd Amr-ı rê̂se mudârebeye akçe verip Amr alıp nakde bey' edemeyip nesîe bey' eylese Zeyd kabul etmeyip Amr'dan filhâl nakit almağa kâdir olur mu? el-Cevab: Olmaz. Ebussuûd. ${ }^{143}$

\subsection{Mudârebede Elde Edilen Kârın Paylaşımıyla İlgili Sorunlar}

Ortaklar arasında kârın paylaşımıyla ilgili çeşitli ihtilafların çıktığı görülmektedir. Rabbü'l-mâl mevcut sermayenin ana sermaye olduğunu iddia ederken mudârib ise farklı iddiada bulunabilmektedir:

Zeyd mudârib-i Amr'in yedinde olan binbeşyüz guruş için “Cümlesi re's-i maldır” deyu dava ve Amr "Bin guruşu re's-i maldır mâadaâsı ribhdir” deyu dava edip tarafeynin beyyineleri olmasa kavil hangisinindir? el-Cevab: Amr'ındır. ${ }^{144}$

140 Ebussuûd, Mecmûatü’l-fetâvâ (İstanbul Müftülüğü Kütüphanesi, 187), vr. 150b-151a.

${ }^{141}$ Ebussuûd, Mecmûatü'l-fetâvâ (İstanbul Müftülüğü Kütüphanesi, 187), vr. 151a; Benzer fetva için bk. Sun'ullah Efendi, Fetâvâ (Hüsnü Paşa, 502), 55a.

${ }^{142}$ Henüz mudârebe ortaklığı faaliyete geçmeden re'sü-mal olan mangırın raviçken kâsid olmasıyla ilgili meydana gelen zararla ilgili fetva için bk. Feyzullah Efendi, Fetâvâ-yı Feyziyye, 339, 2035 no'lu fetva.

143 Ebussuûd, Mecmûatü'l-fetâvâ (İstanbul Müftülüğü Kütüphanesi, 187), vr. 151a.

144 Yenișehirli Abdullah Efendi, Behcetü'l-Fetava, 490; Mudâribin kârın fetva için bk. Feyzullah Efendi, Fetâvâyı Feyziyye, 336, 2020 no'lu fetva. 
Bazen rabbü'l-mâl zorbalıkla ana sermaye ve kârı bütünüyle almaktadır. ${ }^{145}$ Bazen de mudârib rabbü'l-mâli hoşnut etmek için henüz fiilen gerçekleşmemiş bir kârı takdim edebilmektedir. ${ }^{146} \mathrm{Bu}$ durumda mudâribin ticaret neticesinde kâr oluşmaması halinde mudâribin kâr diye verdiğinin asıl sermayeye tutulup tutulmayacağı sorunu ortaya çımaktadır:

Zeyd-i mudârib mâl-i mudârebe ile iştirâ ettiği metâı satmadın "fâide ve ziyânı hisâb ettim" deyû rabbü'l-mâle bir akçe verse ba'dehû metâı bey' ettikde kat'â fâide görmese rabbü'l-mâl bu takdirce fâide deyû aldığı akçe asl-1 mâldan mı olur yoksa ribh mi deyû alır? el-Cevab: Rabbü'l-mâl tafsîl-i mezbûra mu'terif ise yâhud "fâide ettim" deyû Zeyd'in ikrârı bey' olunmadın ziyâde bahâ etmek recâsına mebnî idüğü sâbit (ise) asl-1 mâldandır. Ve illâ Zeyd ikrârı ile muâhazdır. Sonra "fâide etmedim" dediği mesmû olmaz. Ebussuûd. ${ }^{147}$

Zeyd Amr'dan mudârebe ile bir miktar akçe alıp nice defa fayda edip faydasın Amr ile üleşirler iken teaddî ve taksirsiz ziyan eylese Zeyd ziyanını Amr’a çektirmeğe kâdir olur mu? el-Cevab: Olmaz. Ülesdikleri ribhi re'simâl verine korlar. Ebussuûd. ${ }^{148}$

Mudâribin önce kâr etmesi daha sonra zarar etmesi mümkündür. Kârın pavlassımından zarar ve zivanın ortaya çıkması durumunda önceki kârın da asıl sermayeye ilave edilmesi gerekmektedir:

Zeyd Amr'a mudârebe bir miktar akçe verse fâide ve ziyân beraber olur mu? el-Cevab: Fâide bir ibrâdır amma ziyân fâide etmeden vâki olup Amr'ın teaddî ve taksîri ile oldu ise cümle Amr üzerinedir. Amma sonra bâkîden ribh hâsıl olıcak asıl tekmîl olunup bir miktar fâide hâsıl olup Zeyd ile Amr kısmet ettiklerinden sonra ziyân vâki olup Amr'in asla teaddî ve taksîrsiz oldu ise Zeyd ile Amr beraber çekip kısmet ettikleri ribhi yine asla zammedip re'simâl tekmîl lâzımdır. Ebussuûd. ${ }^{149}$

Bazen mudârib elde ettiği kârı rabbü'l-mâl ile paylaşmak istemediği hallerde rabbü'l-mâl ise kâr edildiğini ispat ettiği takdirde kâra ortak olmaktadır:

Zeyd Amr'a mudârebeye akçe verip nice zaman kullanıp "Ribh hâsıl olmadı" dese Zeyd, ribh hâsıl olduğunu isbât eylese Amr'dan hissesin almağa kâdir olur mu? el-Cevab: Olur. Ebussuûd. ${ }^{150}$

Mudârib elde ettiği kârı rabbü'l-mâlin izni dışında kullanamaz. Kullandığı takdirde gâsıp ile ilgili hükümler geçerli olmaktadır:

Zeyd Amr'a mudârebeye verdiği akçe ile Amr bir gemi bina edip bir sefer edip fâide oluştuktan sonra Amr gemi dahi bey' edip fâide edicek geminin fâidesinden Zeyd'e vermemeğe kâdir olur mu? el-Cevab: Zeyd akçe gemi binâsı îçün verdi ise gemi Zeyd'indir. Ve illâ Amr'indır. Akçe gasbetmiş olur. Aslın odur. Ebussuûd. ${ }^{151}$

${ }^{145}$ Fevzullah Efendi, Fetâvâ-vı Fevzivve, 337, 2026 no'lu fetva.

${ }^{146}$ Feyzullah Efendi, Fetâvâ-yı Feyziyye, 339, 2037-2038 no'lu fetva.

147 Ebussuûd, Mecmûatü'l-fetâvâ (İstanbul Müftülüğü Kütüphanesi, 187), vr. 153b.

148 Ebussû̂d, Mecmûatü'l-fetâvâ (İstanbul Müftülüğü Kütüphanesi, 187), vr. 153a.

149 Ebussuûd, Mecmûatü'l-fetâvâ (İstanbul Müftülüğü Kütüphanesi, 187), vr. 150a; Düzdağ, Şeyhülislâm Ebussuûd Efendi'nin Fetvaları, 161; Benzer fetva için bk. Feyzullah Efendi, Fetâvâ-yı Feyziyye, 335.

150 Ebussuûd, Mecmûatü'l-fetâvâ (İstanbul Müftülüğü Kütüphanesi, 187), vr. 151a-b.

151 Ebussû̂d, Mecmûatü'l-fetâvâ (İstanbul Müftülüğü Kütüphanesi, 187), vr. 152b; Benzer fetva için bk. Yenişehirli Abdullah Efendi, Behcetü'l- Fetava, 484. 
Rabbü’l-mâl mudâribin ortaklığa ihanet ettiği gerekçesiyle satın alınan malın yarısını mudâribe satarak sermayeyi kurtarmaya çalıştığı görülmektedir. Bu durumda mudârib rabbü'l-mâldan ecr-i misil ücret alıp alamayacağı fetvaya konu edilmektedir:

Zeyd Amr'a mudârebeye bir miktar akçe verip Amr Zeyd emrettiği metâı alıp sefer eyleyip yedi aydan sonra gelip Zeyd Amr'a "Sen hıyânet edersin" deyû mezbûr metâın nısfin aldığı kıymete Amr’a bey' edip mudârebeyi fesh eylese Amr, Zeyd'den yedi ay ettiği hizmet mukâbelesinde ecr-i misil almağa kâdir olur mu? el-Cevab: Terâzî ile mudârebeyi feshedip Amr metâın nısfin aldığı bahâya kavil edip ondan hâsıl olan ribh cümleden hâsıl olacak ribhin nısfina tutmak olur, alamaz. Ebussuûd. ${ }^{152}$

\subsection{Mudârebenin Hükmüne Aykırı Şartlardan Kaynaklanan Sorunlar}

Rabbü'l-mâl re'sümâli zarardan korumak için mudârebe akdinin ruhuna aykırı mudâribin zarara müşterek olması ve sermayeye kefil alması gibi bazı şartlar ileri sürülebilmektedir:

Zeyd Amr'a bir miktar akçe mudârebeye verdikde "Hüsrân beynimizde müşterek olsun" deyip Amr dahi kabul etmiş olsa Amr tasarruf edip mal helâk olsa hüsrânda müşterek olur mu? el-Cevab: Olmazlar. Helâk üzerinedir. Ebussuûd. ${ }^{153}$

Mudârebeye verilen mala kefil alınamaz. Ancak mudârib teaddi ettiği takdirde şeklinde kayıt düşülürse kefil alınabilir, bu durumda zaten mudârib sermayeyi gasp etmiş olmaktadır:

Mâl-i mudârebeye kefâlet câiz olur mu? el-Cevab: Mudârib teaddî ettiği takdircekefil dedi ise olur gasp etmiş olur. Ebussuûd. ${ }^{154}$

Zeyd Amr'a mudârebe verdiği mala kefil olan Bekir'den gâib iken re'simâli Bekir ahzedip bir miktar dahi ribh deyû ahz eylese Zeyd'in re'simâl ve ribhden aldığı helâl olur mu? el-Cevab: Olmaz. Mâl-i mudârebeye kefâlet sahîha değildir. Ebussuûd. ${ }^{155}$

Zeyd-i reîs Amr'dan mudârebeye bir miktar akçe alıp Bekir mala kefîl olsa Zeyd'in gemisi mâl-i mudârebe ile helâk olup Amr akçesini Bekir'den alıcak Bekir dahi Zeyd'den almağa kâdir olur mu? el-Cevab: Mâl-i mudârebeye kefâlet sahîha değildir meğer ki hıyânet ettiği sâbit olmayınca zamân yoktur. Bekir akçesini Amr'dan yine alır. Ebussuûd. ${ }^{156}$

Zeyd'den Amr-1 reîs mudârebeye bir miktar akçe alıp Bekir kefil olsa Amr'in gemisiyle mâl-i mudârebe helâk olsa zamân lâzım olur mu? el-Cevab: Mâl-i mudârebeye kefâlet sahîha değildir. Bekir: Hıyânet ederse ben kefîl dedi ise öyle ise dahi hıyânet ettiği isbât olıcak zamân yoktur. Bekir'den nesne aldı ise geri reddolunur. Ebussuûd. ${ }^{157}$

\subsection{Mudârebede Ortaklarla İlgili Sorunlar}

\subsubsection{Zimmîyle Mudârebe}

Osmanlı toplumunda zımmîler cemiyetin ayrılmaz bir parçasıdır. Müslümanlarla çok yakın münasebetler içindedir. Müslümanlarla mudârebe akdi yapabilmektedirler.

\footnotetext{
152 Ebussuûd, Mecmûatü'l-fetâvâ (İstanbul Müftülüğü Kütüphanesi, 187), vr. 151b.

153 Ebussuûd, Mecmûatü'l-fetâvâ (İstanbul Müftülüğü Kütüphanesi, 187), vr. 150a.

154 Ebussû̂d, Mecmûatü'l-fetâvâ (İstanbul Müftülüğü Kütüphanesi, 187), vr. 153b.

155 Ebussuûd, Mecmûatü'l-fetâvâ (İstanbul Müftülüğü Kütüphanesi, 187), vr. 152a.

156 Ebussuûd, Mecmûatü'l-fetâvâ (İstanbul Müftülüğü Kütüphanesi, 187), vr. 151b, 153b.

157 Ebussuûd, Mecmûatü'l-fetâvâ (İstanbul Müftülüğü Kütüphanesi, 187), vr. 153b.
} 
Bazı Müslümanlar dinen haram olan şarap vb. işleri zımmîler marifetiyle icra edebilmektedir. Fetvada müslümanın meşru olmayan emrinin boş söz manasında lağv olarak değerlendirilmektedir:

Zeyd Amr-1 zimmîye mudârebeye verdiği akçe ile Amr Zeyd'in emri ile hamr alıp fayda etse Zeyd'e fayda helâl olur mu? el-Cevab: Emir lağv olur. Bey' u şirâ zimmî kendi ehliyeti ile eder. Ebussuûd. ${ }^{158}$

Osmanlı toplumunda o dönemlerde kölelik mevcuttur. Bazı köleler mevlaları tarafından bazı iş ve işlemleri yapmak üzere salahiyetli kılınabilir ve böyle kimselere abd-i me'zun denir. Fetvalarda efendinin izni kölesinin bir başkasıyla mudârebe akdi yapmasına engel olmaya çalıştı̆̆ı görülmektedir:

Zeyd'in abd-i me'zûnuna mudârebeye Amr bir miktar verse Zeyd “Abd-i me'zûnuma mudârebeye ne almışsın rizâm olmadan” demeğe kâdir olur mu? el-Cevab: Re'simâl-i mudârebeyi sâhibine verdirmeğe kâdirdir. Ebussuûd. ${ }^{159}$

Mudâribin gâibken ölmesi durumunda rabbü'l-mâl de diğer alacaklılar gibi geri de kalan maldan hissesini almaya çalışmaktadır:

Bir nice kimesnelere medyûnken fevt olan Amr'ın "Zeyd'e şu miktar akçe verdim" deyû beyyine ikâmet eyleyip miktâr-1 mezbûrun cümlesin alıp taksîm-i guremâda dâhil olmamağa kâdir olur mu? el-Cevab: Olmaz. Mechûlen fevt olmak ile sâir düyûn gibi mâl-i mudârebe zimmetine lâzım olur. Ebussuûd. ${ }^{160}$

\subsubsection{Ortaklardan Birinin Ölmesi}

Mudârebede ortaklar karşılıklı anlaşmayla akdi sona erdirebilecekleri gibi taraflardan birinin vefatıyla da akit kendiliğinden sona ermektedir. Bu durumda hukuki bazı sorunlar ortaya çıkmaktadır. Bu sorunlar rabbü’l-mâlin veya mudâribin ölmesine göre değişiklik arz etmektedir.

\subsubsection{Rabbü'l-mâlin Ölmesi}

Rabbü'l-mâlin ölümünden sonra ortaklık batıl olup ${ }^{161}$ kendiliğinden sona erer. ${ }^{162} \mathrm{Fa}$ kat belli bir süre tayin edilerek yapıldığı takdirde ortaklık ancak sürenin nihayete ermesiyle son bulunmaktadır:

Zeyd mudârebeye aldığı metâı âhar vilâyete iletip ve birine verse bu esnâda rabbü'lmâl fevt olsa veresesi kable-hulûli'l-ecel Zeyd'e "Re'simâli ver" demeğe kâdir olur mu? elCevab: Olmazlar. Ebussuûd. ${ }^{163}$

158 Ebussuûd, Mecmûatü'l-fetâvâ (İstanbul Müftülüğü Kütüphanesi, 187), vr. 153a; Düzdağ, Şeyhülislâm Ebussuûd Efendi'nin Fetvaları, 93

159 Ebussuûd, Mecmûatü'l-fetâvâ (İstanbul Müftülüğü Kütüphanesi, 187), vr. 152b-153a.

160 Ebussuûd. Mecmûatü'l-fetâvâ (İstanbul Müftülüğü Kütüphanesi, 187), vr. 152b.

161 Feyzullah Efendi, Fetâvâ-yı Feyziyye, 337, 2022-2023, 2025 no'lu fetva.

162 Zeyd Amr'dan mudârebe tarikiyle aldığı akçe ile amel etmeden Amr fevt olsa mudârebe bâtıle olur mu? el-Cevab: Olur. Bu surette Zeyd meblağ-i mezbur ile Amr'ın fevtinden sonra amel edip şu kadar faide hâsıla olduktan sonra Zeyd meblağ-1 mezburu Amr'ın veresesine verse "Fâide-i merkûmeden dahi bize hisse ver" deyu cebre kâdir olurlar mı? el-Cevab: Olmazlar. (Yenişehirli Abdullah Efendi, Behcetü'l-Fetava, 484). Zarar olması halinde ise tazmin eder. Yenișehirli Abdullah Efendi, Behcetü'l- Fetava, 486-487.

163 Ebussuûd, Mecmûatü'l-fetâvâ (İstanbul Müftülüğü Kütüphanesi, 187), vr. 151a. 
Mudârib sermayeyi o esnadaki kârıyla birlikte vârislerine iade etmesi gerekir. Kârı masraflara sarf etmesi halinde vârisler anapara dışında kâr isteyemez. ${ }^{164}$ Ancak mudârib mudârebe sermayesiyle mal alıp henüz nakde dönmeden rabbü'l-mâl vefat ederse vârisler nakde döndüğündeki kârdan pay isteyebilir. ${ }^{165}$ Teslim etmeyip bu esnada sermaye zayi olması halinde tazmin etmesi gerekir, verese izinsiz ${ }^{166}$ işletmeye devam etmesi halinde ise tasarrufları hukuken gasp çerçevesinde değerlendirilmektedir:

Zeyd Amr'a bir miktar akçe mudârebeye verdikten sonra Amr nice zaman işletip sonra on yıl gâib gitse mezbûr Amr gâibde iken Zeyd fevt olsa sağîre (kızı) kalıp bâliğa oldukda Amr gelicek Zeyd'in akçesin ribhiyle almağa kâdir olur mu? el-Cevab: Zeyd fevt oluncaya değin hâsıl olan ribhi alır sonra hâsıl olanı alımaz. Zeyd'in fevti ile mudârebe tamam olur. Ondan sonra tasarrufu gasb olur. Hatta mal zâyi olsa zamân lâzımdır. Ebussuûd. ${ }^{167}$

Zeyd Amr-1 reîse mudârebeye bir miktar akçe verip "Ribhinden ne hâsıl olursa oğlum Bekir'e nısfın veresin” dedikten sonra Amr akçe tasarruf edip ribhinden Bekir'e hissesin teslîm edip ba'de zemânin Zeyd fevt olup akçe Amr'dan alınmayıp bir nice yıl Amr tasarruf edip Bekir'e verir iken gemi paralanıp akçe dahi helâk olsa Zeyd'in gâib olan oğlu Bişr meblağ-1 merkûmu Amr'dan tazmîne kâdir olur mu? el-Cevab: Zeyd fevt olmağla mudârebe bâtıl olur. Ondan sonra akçeyi kullanmak ile Amr gâsıb olur. Zamân lâzımdır. Amma Zeyd fevt olduktan sonra Bekir'e verdiği ribh Bekir'in hissesine tutulur. Amr'dan Bişr hissesini tamam alır. Ebussuûd. ${ }^{168}$

Mudâribin sermayanin helak olduğu iddiası ise ancak rabbü'l-mâl hayattayken emrine muhalefet edip etmediğinin, işletirken teaddi ve taksiri olup olmadığının tahkik edilmesinden sonra yemin etmesi şartıyla kabul edilmektedir:

Zeyd Amr'a mudârebeye bir miktar akçe verip ba'dehû fevt oldukda Amr seferden gelip vârislerine "Mâl-i mudârebe helâk oldu" deyû yemîn eylese şer'an zamândan halâs olur mu? el-Cevab: Eğer Zeyd hayatta iken emrine muhâlefet etmedin ve teaddî ve taksir etmedin helâk olduğuna yemîn edip halâs olur. Eğer birisi vâki oldu ise yâhud Zeyd'in fevtinden sonra helâk oldu ise akçe bir defa nakit olup ondan sonra metâ alıp ondan sonra helâk oldu ise zamân lâzımdır. Ebussuûd. ${ }^{169}$

\subsubsection{Mudâribin Ölmesi}

Mudâriblerin çokluğu halinde onlardan biri vefat ettiği takdirde diğer ortağın re'sümâli tam olarak geri ödemesine rağmen bazı veresenin diğer ortaktan da re'sümâl tahsil etmeye çalıştıkları görülmektedir:

Zeyd ile Amr Bekr'den mudârebeye bir mikdar akçe aldıkdan sonra Zeyd fevt olub Amr zikrolunan akçe-i bi't-tamâm Bekr'e teslîm eyledikden sonra verese-i Zeyd akçenin nısfin Zeyd almış idi deyû Amr'dan taleb edüb almağa kâdir olur mu? Beyân buyurulub

\footnotetext{
${ }^{164}$ Fevzullah Efendi. Fetâvâ-vı Fevzivve. 338, 2028 no'lu fetva.

165 Feyzullah Efendi, Fetâvâ-yı Feyziyye, 338, 2033 no'lu fetva.

166 Verese izniyle mudarebeye devam edilmesiyle ilgili fetva için bk. Feyzullah Efendi, Fetâvâ-yı Feyziyye, 336 2019 no'lu fetva.

${ }^{167}$ Ebussuûd, Mecmûatü'l-fetâvâ (İstanbul Müftülüğü Kütüphanesi, 187), vr. 152a-b.

${ }^{168}$ Ebussuûd, Mecmûatü'l-fetâvâ (İstanbul Müftülüğü Kütübhanesi. 187), vr. 150b; Mudâribin köle işi yapmasının men edildiği fetva için bk. Feyzullah Efendi, Fetâvâ-yı Feyziyye, 336, 2020 no'lu fetva.

169 Ebussuûd, Mecmûatü'l-fetâvâ (İstanbul Müftülüğü Kütüphanesi, 187), vr. 153a.
} 
müsâb oluna. el-Cevab -Allah-u a'lem- : Olmazlar. Sahibine teslîm olundukdan sonra Amr'ın teslîmi ile kendiler teslîmin farkı yokdur. Ketebehû Ebussuûd el-hakîr ufiye anhü. ${ }^{170}$

Fetvalarda mudâribin zimmetinde olan devnin mudârebe ortaklığından kaynaklanan borçlardan daha öncelikli olduğu anlașılmaktadır. Devn, genis anlamda "zimmette sabit olan șev" dive tarif edilir. ${ }^{171}$ Bir baška anlamda devn, vâcip bir fiilin vani itibarî malı teslim ișleminin adıdır." ${ }^{172}$ Mudârebeden olan devn ile karz cihetinden olan devn ödeme esnasında esit olamaz. Ancak teaddi ve öldüğünü bilmeden islem vaparsa bu durumda tazmin sorumluluğu doğar. Bu durumda mal mudârebelikten çıkarak deyne dönüşür diğer deynlerle eşit hale gelir:

Mâl-i mudârebeden olan deyn ile karz cihetinden olan deyn taksîm-i guremâda tesviye olunur mu? el-Cevab: Mâl-i mudârebeden deyn olmak muhâldir. Ya teaddîile mücehhelen fevt ile zamân lâzımdır. Olmayınca ehad-i vecheyn ile zamân lâzım olıcak mal mudârebelikten çıar deyn olur sâir düyûna müsâvidir. Ebussuûd. ${ }^{173}$

Zeyd-i rê̂s medyûnen fevt olsa dâyini Amr vârisi yüzüne deyni isbât edip aldıkda mudârebeye mal veren kimesneler "Bizim yüzümüze isbât eyle" demeğe kâdir olur mu? el-Cevab: Olmazlar deyn mal-ı muhît olmayıcak. Ebussuûd. ${ }^{174}$

Mudârib iş yolculuğu esnasında vefat ettiğinde beraberindeki malın devlet korumasına alındığı veresenin devletten onu teslim aldığını ve rabbü’l-mâlin de söz konusu sermayenin mudârebe malı olduğunu ispat ederek vereseden geri almaya çalıştı̆̆ı görülmektedir:

Zeyd mudârebe ile Amr'a yedi bin akçe verip Amr bir vilâyette ölüp Beytülmâl metrûkâtın zabtedip veresesi varıp emîn elinden yedi bin akçesin isbât eyleyip alsalar Zeyd meblağ-ı merkûmu veresenin elinden almağa kâdir olur mu? el-Cevab: Olur. Ebussuûd. ${ }^{175}$

Zeyd Amr-1 reîse mudârebeye akçe verip Amr nice yıllar akçeyi kullanıp ba'dehû Amr fevt olup cümle terike Bekr-i vârise müntakil olup Zeyd akçesini Bekir'in yüzüne isbât edip terike-i Amr'dan aslını ve faydasını almağa kâdir olur mu? el-Cevab: Olur faydasın dahi isbât edicek. Ebussuûd. ${ }^{176}$

\subsection{Mudârebeyle İlgili Yasal İşlemler}

Mudârebe ortaklığıyla ilgili birçok ihtilafın çıktığı ve bazısının mahkemelere yansıdığı görülmektedir. Bu asırlara ait şer'iyye sicillerinde mudârebeyle ilgili bazı kayıtlara rastlanmaktadır. ${ }^{177}$ Fetvalarda da dava süreciyle ilgili bazı ifadelere rastlanmaktadır.

\footnotetext{
170 Komisvon, Mecmûatü'l-fetâvâ (Şehid Ali Paşa, 2867), vr. 75a.

171 Mecelle, Md. 158.

172 Kâsânî, Bedâiu's-Sanâi, 7/196; Mehmet Âkif Aydın, “Deyn”, Diyanet İslam Ansiklopedisi, (İstanbul: TDV Yayınc1lik, 1994), 9/266-268.

173 Ebussuûd, Mecmûatü'l-fetâvâ (İstanbul Müftülüğü Kütüphanesi, 187), vr. 150a.

174 Ebussuûd, Mecmûatü'l-fetâvâ (İstanbul Müftülüğü Kütüphanesi, 187), vr. 153b.

175 Ebussuûd, Mecmûatü'l-fetâvâ (İstanbul Müftülüğü Kütüphanesi, 187), vr. 152a.

176 Ebussuûd, Mecmûatü'l-fetâvâ (İstanbul Müftülüğü Kütüphanesi, 187), vr. 150b.

177 Gedikli, Osmanlı Şirket Kültürü, 102-120.
} 
Fetva, şer'î hükmü açıklamakta yani bir nevi istişârî mahiyettedir. Burada kadının görevi, fetvalardan davayla ilgili olanı bulup belli bir hükme ulaşmaktır. Bu açıdan kazâ, fetvanın uygulamaya bakan yönüdür. Kadı âmme velâyetine, müftü ise ilmî selâhiyetine istinâden görev yapmaktadır. ${ }^{178}$ Bu dönemde kadılar, ihtiyaç duymaları hâlinde müftülerden fetva isteyebilmektedir. ${ }^{179}$ Kadılar, reddine yönelik hukuki gerekçeleri olmadan bir fetvanın aksine hüküm veremez. Dolayısıyla mudârebe ortakları, her aşamada müftüye başvurabilmekte, bazen kadıdan aldıkları ilâmı müftülere götürüp inceletmektedir. Bir fetvada mudâribin helak olduğuna dair beyanı hâkim tarafından tahkik edilmekte, sayı konusundaki yalanının tazmini gerektirip gerektirmediği araştırılmaktadır:

Zeyd-i reîsin gemisi paralanıp içinde olan mâl-i mudârebe zâyi oldukda kâdı, Zeyd'e adedinden suâl edip Zeyd'in mücerred adedinde kizbi zâhir olmak cümle malı tazmîn ettirmeye kâdir olur mu? el-Cevab: Kâdir olmaz taksirinsiz paralandı dedikde sâdık olıcak. Ebussuûd. ${ }^{180}$

Zeyd'in âhar şehirdeki Amr üzerindeki mâl-i mudârebe içün getirilen nakl-i şehâdede “Amr'ın mukırr idüğü(ikrar ettiği) ya münkir idüğü Amr yazılmamış” deyû kâdîi mektûbun ileyh tutmamağa kâdir olur mu? el-Cevab: Şâhidler "Amr'nn zimmetinde deyû" şehâdet ettiler ise inkârı ya teaddîsi ya muhâlefeti yazılmak lâzımdır. "Elinde deyû" şehâdet ettilerse naklin sâir cihetinden haleli yok ise kabûl meşrûdur. Ebussuûd. ${ }^{181}$

\section{Sonuç}

Osmanlı dönemi fetva literatüründe mudârebe akdi, fikıh geleneğinde olduğu gibi şirket bölümünden ayrı müstakil başlıklarda yer almaktadır. Mudârebeyle ilgili fetvaların daha çok uygulama esnasında ortaya çıkan sorunlar ve çözümleri yansıttığı anlaşılmaktadır. 16. ve 18. asırlara ait öne çıkan fetva mecmuaları incelendiğinde gerek sayı gerekse ihtiva ettiği konular bakımından mudârebe ortaklığının Osmanlı toplumunda vavgın bir sekilde kullanıldığı görülmektedir. Zira bu ortaklık sermavedar açısından sermavesini isletmenin, girișimci açısından da finansman ihtiyacını karşılamanın en kullanışlı araçlarından biri olduğu söylenebilir. Özellikle ticaret yapma imkânı olmayan bazı kimselerin bu ortaklığı tercih etmeleri söz konusudur. Mudâribin ortaklıkta faal, rabbü'l-mâlin pasif kalması ortakların daha çok ihtilafa düşmesine imkân verdiği anlaşılmaktadır. Bu durumun diğer ortaklık türlerine göre mudârebeyle ilgili meselelerin daha fazla fetvalara yansımasina sebep olduğu söylenebilir.

Mudârebeyle ilgili fetvalarda sıkça geçen denizle ilgili "Zevd-i reis", "Karadeniz ve Akdeniz" gibi ifadeler söz konusu asırlarda Osmanlı Devleti’nde daha çok İstanbul merkezli Akdeniz ve Karadeniz havzasında tarım ve ticarete vönelik ișler için mudârebe ortaklığı vapıldığı görülmektedir. Bu sayede girişimciler, kısa vadeli finansman ihtiyaçlarını karşıladıkları anlaşılmaktadır.

\footnotetext{
178 İsmail Hakkı İzmirli, Kitâbu'l-ifftâ (İstanbul: Evkaf Matbaası, 1336), 5; Ali Himmet Berki, Hukuk Tarihinde İslâm Hukuku (Ankara: Diyanet İşleri Reisliği Yayıncılık, 1955), 52; Murat Akgündüz, Osmanlı Devleti’nde Şeyhülislâmlık (İstanbul: Beyan Yayıncilık, 2002), 219-220.

179 Mehmed Aziz Çavuşzâde, Dürrü's-Sükûk, (İstanbul: Âmire Matbaası, 1277), 1/73.

180 Ebussuûd, Mecmûatü'l-fetâvâ (İstanbul Müftülüğü Kütüphanesi, 187), vr. 151a.

181 Ebussuûd, Mecmûatü'l-fetâvâ (İstanbul Müftülüğü Kütüphanesi, 187), vr. 125a.
} 
Araştırmada mudârebe ortaklığında mudâribin teaddisi olmadığı takdirde re'sümâldeki zarardan sorumlu olmaması ve rabbü’l-mâlin takyidine muhalif yaptı̆̆ı işlemlerden dolayı kâr etmesi halinde kârın kendisine kalmasıyla mudâribin daha fazla risk almasına imkân verdiği görülmektedir. Bu durum rabbü’l-mâlin sermayesini zarardan korumak amacıvla mudâribe ver. zaman ve süreyle ilgili çeşitli sınırlamalar getirmeye çalışmasına hatta daha da ileri giderek mudâribin sermayedeki zarara müşterek olması veya sermayeye kefil olması gibi fikıhta yer aldığı şekliyle mudârebe akdinin ruhuna avkırı bazı sartlar ileri sürmesine sebep olmaktadır. Buna rağmen mudâribin ilgili sartlara pek fazla riâvet etmeverek bazı hallerde sermavenin zâyî olmasına sebep olduğu bunun ise teaddi kapsamında değerlendirildiği anlaşılmaktadır.

Rabbü'l-mâl ile mudâribin temel ihtilaf noktalarından birinin de re'sümâlin karz, muâmele veya mudârebe olarak verilip verilmediği meselesidir. Özellikle ortaklığın zarar etmesi halinde rabbü'l-mâl, ana sermayesini kurtarmak, mudâribin ise tazmin yükümlülüğünden kaçınmak için uğraştığı görülmektedir. Hatta bazı fetvalarda rabbü'l-mâl, mudâribden kâr payı alırken, sermayenin mahiyetini gündem yapmazken zarar ortaya çıktığı hallerde karz verdiğini iddia edebilmektedir. Burada rabbü’l-mâlin karz verdiği iddiasına karşılık, mudârib mudârebeye aldığını ileri sürmektedir. Fetvalarda ortaklar herhangi bir delil ortaya koyamadığı veya her iki tarafın delil ortaya koyduğu hallerde karz delili kabul edilmekte, deliller arasında herhangi bir tercih yapılamadı̆̆ı takdirde ise sermaye zâyî olmuşsa karz, kâr elde edilmişse mudârebe delilinin tercih edildiği görülmektedir. Çünkü mudârib, rabbü'l-mâlin izniyle sermayeyi kabzettiğine göre rabbü’l-mâl de malı teslim ettiğini itiraf etmektedir. Bu durumda mudâribe tazmin davası açabilir. Ancak rabbü’l-mâlin karz verdiğine dair delili olmadığı hallerde mudâribin mudârebe olduğuna dair yemini kabul edilir.

Karzdan kavnaklanan devnin mudârebe ortaklığından kaynaklanan alacaklardan daha öncelikli olduğu anlaşılmaktadır. Ayırca re'sümâlin ve kârın teslimiyle ilgili bazı sorunlar çıktığı anlaşılmaktadır. Bu konuda mudâribin adil ve güvenilir olması halinde re'sümâli rabbü'l-mâle teslim ettiğine dair yemini yeterli görülmektedir.

Fetvalarda rabbü'l-mâlin buğday, kendir, bez ve koyun gibi taşınır malları re'sümâl yapmaya çalıştığı görülmektedir. Ancak rabbü'l-mâl vekâlet verip mudârebeye kullanmasını söylendiği takdirde mudârebe akdi kurulmuş olmadığı görülmektedir. Ayrıca mudâribin emeği dışında kendisinin sermaye ilave ettiğine dair iddiası şu şartlarda kabul edilmektedir:

1) Rabbü'l-mâl tarafından izin verilmiş olmalıdır. İzin verilmeden mudârebeye mal kattığı takdirde yemini tasdik edilmez ve rabbü'l-mâlin verdiği mudârebe sermayesini tazmin etmesi gerekir, mevcut mallar ise kendisinde kalır.

2) Mudâribin satın aldığı ticari ürünlerin mudârebe malı olduğunu ikrar etmiş olmamalıdır. Zira ikrar ettikten sonra kendi malını kattı̆̆ı iddiaları kabul edilmez.

Şayet mudârib, rabbü'l-mâlin bilgisi dâhilinde re'sümâli kendi malına katıp işletirken vefat etmesi halinde ise fetvalarda öncelikle rabbü’l-mâlin korunmaya çalışıldığı görülmektedir. Mudârib mudârebe malını beyan etmeden öldüğü takdirde mevcut mal mudârebe sermavesini karsılamazsa öncelikle re'sümâlin tazmin edilmesi gerekmektedir.

Mudârebevle ilgili zarar ve zivan hususlarının diğer meselelere göre daha fazla fetvalara konu olduğu söylenebilir. Bunların bir kısmı mudâribin ihmal ve kötü niyetli tutumundan bir kısmı olumsuz piyasa şartlarından diğer bir kısmı da geminin batması gibi 
fizikî olumsuz șartlardan kavnaklandığı görülmektedir. Bunlardan hareketle söz konusu asırlarda zararın kavnaklandığı alanları tespit etmek de mümkündür. Bunlar arasında deniz araçlarının batma ve yan yatmaları öne çıkmaktadır.

Mudârebe akdi örneğinde araştırma yapılan asırlarda fetvalarla fikıh geleneği arasında yani teori ile pratik arasında bir uyumsuzluğa rastlanmadığı söylenebilir. Bu ortaklık, günümüzde faize dayalı iktisadi düzenden kurtaracak alternatif yollardan biri olarak ileri sürülmektedir. Bu tür iddiaların araştırma yapılan dönemlerle ilgili tecrübeleri göz ardı ettikleri anlaşılmaktadır. Bu alanda değişen ticari örfü dikkate almadan vapılacak öneriler temenniden öte bir anlam ifade etmeyecektir. Avrıca "Mülkivetle Sona Eren Mudârebe", "Müşterek Mudârebe" ve "Mudârebe Sukuk" gibi içinde mudârebe ismi geçen çeşitli çağdaş mudârebe ortaklıklarının klasik mudârebe ortaklığına dair hükümleri esas alarak değerlendirmek pek de isabetli bir yaklaşım olmayacaktır. Zira bu ortaklık yapıları çağımızın bir gereği olarak mürekkep, karma ve kendine özgü mahiyette olabilmektedir. Dolayısıyla akitlerle ilgili genel ilkeler çerçevesinde adalet ve hakkaniyet ölçülerine göre hüküm vermek daha isabetli bir yaklaşım olacaktır.

\section{Kaynakça}

Akgündüz, Murat. Osmanl Devleti’nde Şeyhülislâmlk. İstanbul: Beyan Yayıncıllı, 2002.

Apaydın, H. Yunus. “Îne”. Türkiye Diyanet Vakfi İslam Ansiklopedisi 22/283-285. İstanbul: TDV Yayınları, 2000.

Apaydın, H. Yunus. “Karz”. Türkiye Diyanet Vakfi İslam Ansiklopedisi 24/520-525. İstanbul: TDV Yayınları, 1995.

Arslanl, Halil. Kollektifve Komandit Şirketler. İstanbul: İstanbul Üniversitesi Yayınları, 1958.

Atar, Fahrettin. “ifttâ Teşkilatının Ortaya Çıkışı”. Marmara Üniversitesi İlahiyat Fakültesi Dergisi 3 (1985), $19-48$.

Aybakan, Bilal. "Muâmele”. Türkiye Diyanet Vakfi İslam Ansiklopedisi 30: 319-320. İstanbul: TDV Yayınları, 2005.

Aydın, Mehmet Âkif. “Deyn”. Diyanet İslam Ansiklopedisi 9/266-268. İstanbul: TDV Yayınc1lk, 1994.

Aydın, Mehmet Âkif. “Gasp”. Diyanet İslam Ansiklopedisi 13/387-392. İstanbul: TDV Yay. 1996.

Aynî, Ebu Muhammed Bedrüddin Mahmud b. Ahmed b. Musa el-Ayıntabi. el-Binaye fi Şerhi'l-Hidaye. IX. Beyrut: Dârü'l-Fikr, 1980.

Bacha, Obiyathulla Ismath. "Conventional Versus Mudārabah Financing: An Agency Cost Perspective". Journal of Islamic Economics 4/1-2 (1995), 33-49.

Bayındır, Servet. Fikhî ve İktisâdî Açıdan İslâmî Finans (Para ve Sermaye Piyasaları) İstanbul: Süleymaniye Vakfı Yayıncillk, 2015.

Berki, Ali Himmet. Hukuk Tarihinde İslâm Hukuku. Ankara: Diyanet İşleri Reisliği Yayıncllı, 1955.

Bilgin, Vejdi. Fakih ve Toplum. İstanbul: İz Yayıncllk, 2003.

Çavuşzâde, Mehmed Aziz. Dürrü’s-Sükûk. İstanbul: Âmire Matbaası, 1277.

Çelik, İmran. "Meşru Bir Yatırım Aracı Olarak Mudârebe ve Günümüzde Kullanımı". Injosos Al-Farabi International Journal On Social Sciences/ Al-Farabi Uluslararast Sosyal Bilimler Dergisi 1/3 (2017), 381395.

Çiller, Tansu-Çizakça, Murat. Türk Finans Kesiminde Sorunlar ve Reform Önerileri İstanbul: İstanbul sanayi Odası Yayıncilik, 1989.

Durmuş, Abdullah. "Modern Bir Finansal Araç Olarak Sukuk ve Fıkhi Açıdan Tahlili”. İslam Hukuku Araștırmaları Dergisi 16 (2010), 141-156.

Düzdağ, M. Ertuğrul. Şeyhülislâm Ebussuûd Efendinin Fetvaları Işığında 16. Astr Türk Hayatı. İstanbul: Şûle Yayıncilk, 1998. 
Ebussuûd, Muhammed İmâduddin. Mecmûatü'l-Fetâvâ. Der. Velî b. Yusuf İstanbul: İstanbul Müftülüğü Kütüphanesi, 178.

Ebussuûd, Muhammed İmâduddin. Mecmûatül-fetâvâ. İstanbul: Süleymaniye Kütüphanesi, Esad Ef., 3406.

Ekinci, Mustafa. Anadolu Alevîliăi’nin Tarihsel Arka Planı. İstanbul: Beyan Yayıncllı, 2002.

Feyzullah Efendi. Fetâvâ-yı Feyziyye. Haz. Süleyman Kaya. İstanbul: Klasik Yayıncıllk, 2009.

Gedikli, Fethi. “İstanbul'da Para Vakıfları ve Mudârebe”. Osmanl Hukuku: Makaleler. İstanbul: Gündoğan Yayınları, 2012, 31-47.

Gedikli, Fethi. Osmanl şirket Kültürü:XVI.-XVII. Yüzyllarda Mudârebe Uygulaması. İstanbul: İz Yayıncıllk, 1998.

Gönen, Doruk. “íslam Hukukunda Mudârebe (Emek+Sermaye) Şirketinde Tarafların Hak ve Borçları”. İstanbul Üniversitesi HukukFakültesi Mecmuası 63/1-2 (2005), 193-212.

Hamdemirci Ahmet- Görmüș, Sakir. “Kapitalizm'in Sarmalından Bir Çııș Yolu Olarak Adil Ekonomik Düzen'in Kredileşme İlkeleri”. Route Education and Social Science Journal 27 (2018), 1296-1316.

Hammâd, Nezih Kemâl. el-Ukûdü'l-mürekkebe fi'l-fikhi'l-̇̇lâmiyyi. Dımeşk: Dâru'l-kalem, 1325/2004.

Hattâb, Abdurrahman Muhammed b. Muhammed. Mevâhibu'l-celil li-şerhi Muhtasar-ı Halil. thk. Zekeriva Umeyrât. Beyrut: Dâr-u âlimi'l-kütüb, 2003.

Hayyat, Abdülaziz İzzet. eș-Şerikât fi'ş-Şeriati'l-İslamiyye ve'l-Kanunu'l-Vaz'ỉ. Beyrut: Müessetür'r-risale, 4. Baskı, 1994.

Heyet. Mecmûatü'l-fetâvâ İstanbul: Süleymaniye Kütüphanesi, Şehid Ali Paşa, 2867.

Huneyni, Muhammed Vecih. "Tasmîmu Hıyârâti Mâliyye İslâmiyye li'l-Mudârebe ve İdâreti'lMehâtır". International Congress on Islamic Economics and Finance (ICISEF) (21-23 October 2015). 2/233-262. Sakarya: Turkey Proceedings, 2016.

İbn Hazm, Ebû Muhammed Ali b. Ahmed b. Saîd el-Endelüsî el-Kurtubî ez-Zahirî. el- Muhallâ bill-âsâr. Beyrût: Dârü'l-ïlmiye, 1988.

İbn İshak, Muhammed b. İshak b. Yesar. Siretü İbn İshak. thk. Muhammed Hamidullah. XIII Cilt. Konya: Hayra Hizmet Vakfi Yayincllık, 1981.

İbn Kemal Paşa, Ahmed b. Süleyman. Fetâvâ. İstanbul: Süleymaniye Kütüphanesi, Âşir Ef., 270.

İbn Kemal Paşa, Ahmed b. Süleyman. Fetâvâ-yl İbn Kemal. İstanbul: Süleymaniye Kütüphanesi, Nuruosmaniye, 1967.

İbn Kemal Paşa, Ahmed b. Süleyman. Fetâvâ-yı Kemalpaşazâde der Hakk-ı Kızılbaş. Süleymaniye Kütüphanesi, Esad Ef., 3548, vr. 45a-47b.

İbn Kemal Paşa, Ahmed b. Süleyman. Îzâhu'l-Islâh. İstanbul: Fatih, 1485.

İbn Kemal Paşa, Ahmed b. Süleyman. Risâlefî Mesâili'l-Fetâvâ. İstanbul: Süleymaniye Kütüphanesi, Yeni Cami, 685.

İbn Kemal Paşa, Ahmed b. Süleyman. Fetâvâ. İstanbul: Süleymaniye Kütüphanesi, Hacı Mahmut Efendi, 1224.

İbn Kemal Paşa, Ahmed b. Süleyman. Mecmau'l-mesâili'ş-șer'iyye fi'l-ulûmi'd-dîniyye. İstanbul Üniversitesi Merkez Kütüphanesi, Nadir Eserler-Türkçe, 6253.

İbnü'l-Esir, İzzeddin Ebi'l-Hasan Ali b. Ebi'l-Kerem. el-Kâmil fitt-tarih. Beyrut: 1965.

İbnü'l-Hümam, Kemalüddin Muhammed b. Abdilvahid b. Abdülhamid. b. Mes'ud. Şerhu Fethi'l-Kadir. Beyrut: Dâru'l-Fikr, 1977.

İnanır, Ahmet. İbn Kemalin Fetvaları Işı̆̆ında Osmanl’da İslam Hukuku. Ankara: Gece Kitaplığı, 2015.

İnanır, Ahmet. Kanûnî Devrinde Osmanli'da Hukukî Hayat. İstanbul: OSAV Yayıncılık, 2011.

İnanır, Ahmet. “XVI. Yüzyıl Osmanlı Devleti’nde Fetvanın Yeri ve Günümüz Osmanlı Araştırmaları Bakımından Kaynak Değeri”. Osmanl'da Fikıh ve Hukuk. ed. Süleyman Kaya - Haşim Şahin. 133149. İstanbul: Mahya Yaymları, 2017.

İzmirli, İsmail Hakkı. Kitâbu'l-iftâ. İstanbul: Evkaf Matbaası, 1336. 
Kallek, Cengiz. "Mudârebe”. Türkiye Diyanet Vakfi İslâm Ansiklopedisi. 30/359-363. İstanbul: TDV Yayınları, 2005.

Kasani, Alauddin Ebu Bekir b. Mes'ud. Kitabu Bedâiu's-Sanâi fi Tertibi'ş-Şerai. Beyrut: Dâru'l-kütübi'l-ilmiyye, 1986.

Komisyon. Faizsiz Bankacıllk Standartları, Çev. İshak Emin Aktepe/Mehmet Odabaşı İstanbul: TKBB Yayıncilk, 2012.

Köse, Murtaza. "Ticaret Hukuku Tarihi Açısından Mudârebe ve Commenda Ortaklıklarının Etkileşimi Hakkında Bir Deneme”. Atatürk Üniversitesi İlahiyat Fakültesi Dergisi 17 (2002), 151-177.

Kumaş, M. Salih \& Abdullayev, Elman. "Bir Finansman Modeli Olarak Mudârebe'nin Faizsiz Bankac1lıkta Etkin Şekilde Kullanılması Sürecinde Sivil Toplum Örgütlerinin Aktif Rol Üstlenmesi”. International Journal of Islamic Economics and Finance Studies = Uluslararast İslam Ekonomisi ve Finansl Araştırmaları Dergisi 2/1 (2016), 67-87.

Merğînânî, Ali b. Ebî Bekir b. Abdulcelil. el-Hidâye şerh-u Bidâyeti'l-mubtedî. thk. Tallâl Yusuf. Beyrut: Dâru kütübi'l-ilmiyye, 1990, 3/225.

Mısrî, Refik Yunus. Buhûsfi'l-mesârifi'l-İlâmiyye. Dımaşk: Dâru'l-fikr, 2001.

Neccâr, Ahmed. el-Asâle ve'l-muâsıra fî menheci tenmiyeti'ş-şâmile; Bünûk bilâ fevâid kadıyyetü bünûki'l-iddihâri'l-mahalliyye Cidde: 1985.

Nevevî, Ebû Zekeriya Muhyiddin b. Şeref. el-Mecmu Şerhu'l-Mühezzeb. Beyrut: Dâru'l-fikr, ts.

Özcan, Tahsin. "Osmanlı Şirket Kültürü: XVI.-XVII. Yüzylllarda Mudârebe Uygulaması". İslâm Araşttrmaları Dergisi 3 (1999), 273-275.

Sahnun, Mahmud-Hannan el-Umravi, "Sukûkü'l-Mudârebeti'l-Hadrâ ve Devruhâ fî Tahkîki Mukavvemâti't-Tenmiyeti'l-Müstedâme". International Congress on Islamic Economics and Finance (ICISEF) 21-23 October 2015. 3/210-220. Sakarya: Turkey Proceedings, 2016.

Savaş, Saim. XVI. Asırda Anadolu'da Alevilik. İstanbul: Vadi Yayıncıllk, 2002.

Serahsî, Ebubekir Muhammed b. Ahmed b. Ebi Sehl. Mebsut. Beyrut: Dâru'l-marife, 1993.

Sun'ullah Efendi. Fetâvâ-yı Sun'ullah Efendi. İstanbul: Süleymaniye Yazma Eserler Kütüphanesi, Hüsnü Paşa, 502.

Şekerci, Osman. İslâm Şirketler Hukuku İstanbul, Marifet Yayınc1lk, 1981.

Şeybânî, Ebu Abdullah Muhammed b. Hasen. el-Camiu's-Sagîr. Beyrut: y.y., 1986.

Şurunbilali, Ebu'l-i̇hlas Hasan b. Ammar b. Ali el-Vefai. Gunyetü Zevi'l Ahkam fi Buğyeti Düreri'l-Hükkam. İstanbul: 1976.

Tekindağ, Şehabettin. "Yeni Kaynak ve Vesîkaların Işı̆̆ı Altında Yavuz Sultan Selim'in İran Seferi”. İstanbul Üniversitesi Edebiyat Fakültesi Tarih-Enstitüsü Dergisi 27/22, (1968), 50-79.

Yenișehirli Abdullah Efendi. Behcetü'l- Fetava Maa'n-Nükul. İstanbul: Dârü't-Tibâati'l-Âmire, 1266.

Yıldız, Yunus Emre. Kamu Kurumlarnin Finansmaninda Mudârebe İmkânlarının Uygulanması. İstanbul: Sabahattin Zaim Üniversitesi, Sosyal Bilimler Enstitüsü, Yüksek Lisans Tezi, 2019.

Zafenî, Abdulelah. Mudârebe Şirketlerinin Akitleri ve Çağdaş Uygulanırlğı. İstanbul: Sabahattin Zaim Üniversitesi, Sosyal Bilimler Enstitüsü, Yüksek Lisans Tezi, 2017. 